\title{
Use of Human Umbilical Vein Endothelial Cells (HUVEC) as a Model to Study Cardiovascular Disease: A Review
}

\author{
Diana J. Medina-Leyte ${ }^{1,2}$, Mayra Domínguez-Pérez ${ }^{1}{ }^{(}$, Ingrid Mercado ${ }^{3}{ }^{(D)}$, \\ María T. Villarreal-Molina ${ }^{1}(\mathbb{D})$ and Leonor Jacobo-Albavera ${ }^{1, *}$ \\ 1 Laboratorio de Genómica de Enfermedades Cardiovasculares, Instituto Nacional de Medicina Genómica, \\ Tlalpan, Ciudad de México 14610, Mexico; dianajhos18@gmail.com (D.J.M.-L.); \\ mdominguez@inmegen.gob.mx (M.D.-P.); mvillareal@inmegen.gob.mx (M.T.V.-M.) \\ 2 Posgrado en Ciencias Biológicas, Universidad Nacional Autónoma de México, \\ Coyoacán, Ciudad de México 04510, Mexico \\ 3 Departamento de Ingeniería Celular y Biocatálisis; Instituto de Biotecnología, Universidad Nacional \\ Autónoma de México, Cuernavaca, Morelos 62210, Mexico; inmede@ibt.unam.mx \\ * Correspondence: ljacobo@inmegen.gob.mx; Tel.: +55-53501900
}

Received: 1 January 2020; Accepted: 27 January 2020; Published: 31 January 2020

\begin{abstract}
Cardiovascular disease (CVD) is the leading cause of death worldwide, and extensive research has been performed to understand this disease better, using various experimental models. The endothelium plays a crucial role in the development of CVD, since it is an interface between bloodstream components, such as monocytes and platelets, and other arterial wall components. Human umbilical vein endothelial cell (HUVEC) isolation from umbilical cord was first described in 1973. To date, this model is still widely used because of the high HUVEC isolation success rate, and because HUVEC are an excellent model to study a broad array of diseases, including cardiovascular and metabolic diseases. We here review the history of HUVEC isolation, the HUVEC model over time, HUVEC culture characteristics and conditions, advantages and disadvantages of this model and finally, its applications in the area of cardiovascular diseases.
\end{abstract}

Keywords: human umbilical cord collection and conservation; endothelial cells; HUVEC model; HUVEC isolation; HUVEC culture conditions; cardiovascular disease

\section{Introduction}

Cardiovascular disease (CVD) is highly prevalent in the adult population and the leading cause of morbidity and mortality globally [1]. While CVD has a complex etiology, atherosclerosis is considered the primary pathological mechanism associated with this disease. Atherogenesis begins with the loss of integrity of the vascular endothelium or endothelial dysfunction, and its progression leads to vessel damage and occlusion that may result in a variety of outcomes, such as thrombosis of the arterial wall, as well as injury and dysfunction of tissues and organs [2,3]. Numerous studies have acknowledged the crucial role of endothelial dysfunction in CVD, so it is necessary to find an optimal model for research of this disease [2,4-6].

Although there are significant advances in the development of animal models for the study of disease, such as transgenic mice, these models frequently fail to faithfully recapitulate the human condition [7]. In fact, several studies have shown that the efficacy and safety of many drugs previously tested in animals fail in human clinical trials $[7,8]$. While studies in animal models have made crucial contributions to research, in vitro tests have the potential to make distinct contributions in testing hypotheses [7-9], as they allow to isolate the object of study, control experimental variables 
and minimize the effect of experimental covariates. In vitro models can represent the complex 3D structure of tissues, allowing the study of the mechanisms and molecular interactions of organisms at different levels: Molecules, cells and organs, both in normal and pathological conditions [7-10]. Over time, the development of in vitro models and specific cell cultures have led to accelerated progress in understanding many diseases, the proposal of novel therapies and the development of novel diagnostic methods.

Studies in human umbilical vein endothelial cells (HUVEC) have been acknowledged as a useful model for research on human endothelium. Although this model does not represent all endothelial cell types found in an organism, HUVEC are an excellent model for the study of vascular endothelium properties and the main biological pathways involved in endothelium function [11]. More recently, this model has been used to study pathophysiological mechanisms involved in the development of CVD. The aim of this review is to provide an extensive and thorough review of human umbilical cord properties, historical and methodological aspects of HUVEC isolation and culture, and to describe different approaches that have been useful to understand CVD and other cardiometabolic conditions.

\section{Why an Endothelial Model?}

The study of human endothelium and endothelial dysfunction has become a central issue in cardiovascular and clinical research. The vascular endothelium is involved in a wide variety of functions and in the pathophysiology of several diseases, including diabetes, hypertension, neoplasms (Kaposi's sarcoma) and CVD [12-14]. Moreover, vascular endothelium alterations are considered initial events in the pathophysiology of various diseases [12]. It is a vital autocrine and paracrine organ that maintains vascular homeostasis, and regulates local cell growth and extracellular matrix deposition [13]. Endothelial cells (EC) produce many different vasculoregulatory and vasculotropic molecules that act at local and distant sites [14]. The endothelium not only functions as a barrier between blood and organs, but it also participates in the transfer of nutrients, hormones and white blood cells, and in anti-inflammatory responses [13].

This organ is also involved in the regulation of blood pressure, blood flow, and coagulation [14]. Because the endothelium participates in wound repair processes, wound-healing or Boyden chamber migration assays with EC can be used to examine this process under different experimental conditions [12,15]. Additionally, EC play a role in angiogenesis and platelet binding to substrates or to the endothelial monolayer under flow conditions [15]. The HUVEC model has been particularly useful in the study of the effects of hemodynamic forces on the endothelium and atherosclerotic plaque formation, since the model allows to expose EC to shear stress controlling flow conditions, and thus, mimicking blood flow conditions in vivo [5].

In vivo models have been widely used to investigate a broad range of biological mechanisms. However, these models are not always the best option, partly because of several technical difficulties. Particularly when attempting to elucidate the contribution of cellular and molecular factors under very specific and controlled conditions, in vitro models are preferred. In recent years, in vitro HUVEC models have been useful to study monocyte adhesion to the endothelium, endothelial damage and repair, the potential impact of atherosclerosis in early stages and atherosclerosis progression [15]. Moreover, studies in HUVEC have the potential to refine the stratification of cardiovascular risk and serve as a guide to monitor the effects of therapeutic interventions.

\section{Umbilical Cord and HUVEC}

\subsection{Characteristics of Umbilical Cord}

The human umbilical cord (HUC) is formed during the fifth week of embryonic development [16]. At the end of pregnancy, it weighs approximately $40 \mathrm{~g}$, reaches a length of 60-65 $\mathrm{cm}$, and has a diameter of $1.5 \mathrm{~cm}[16,17]$. The HUC contains two umbilical arteries and one vein (Figure 1A), all embedded in a mucous matrix of connective tissue with no capillaries or lymphatic vessels, rich in proteoglycans and 
several collagen isoforms, known as Wharton's jelly (WJ) $[16,18]$. WJ derives from the extraembryonic mesoderm [19].
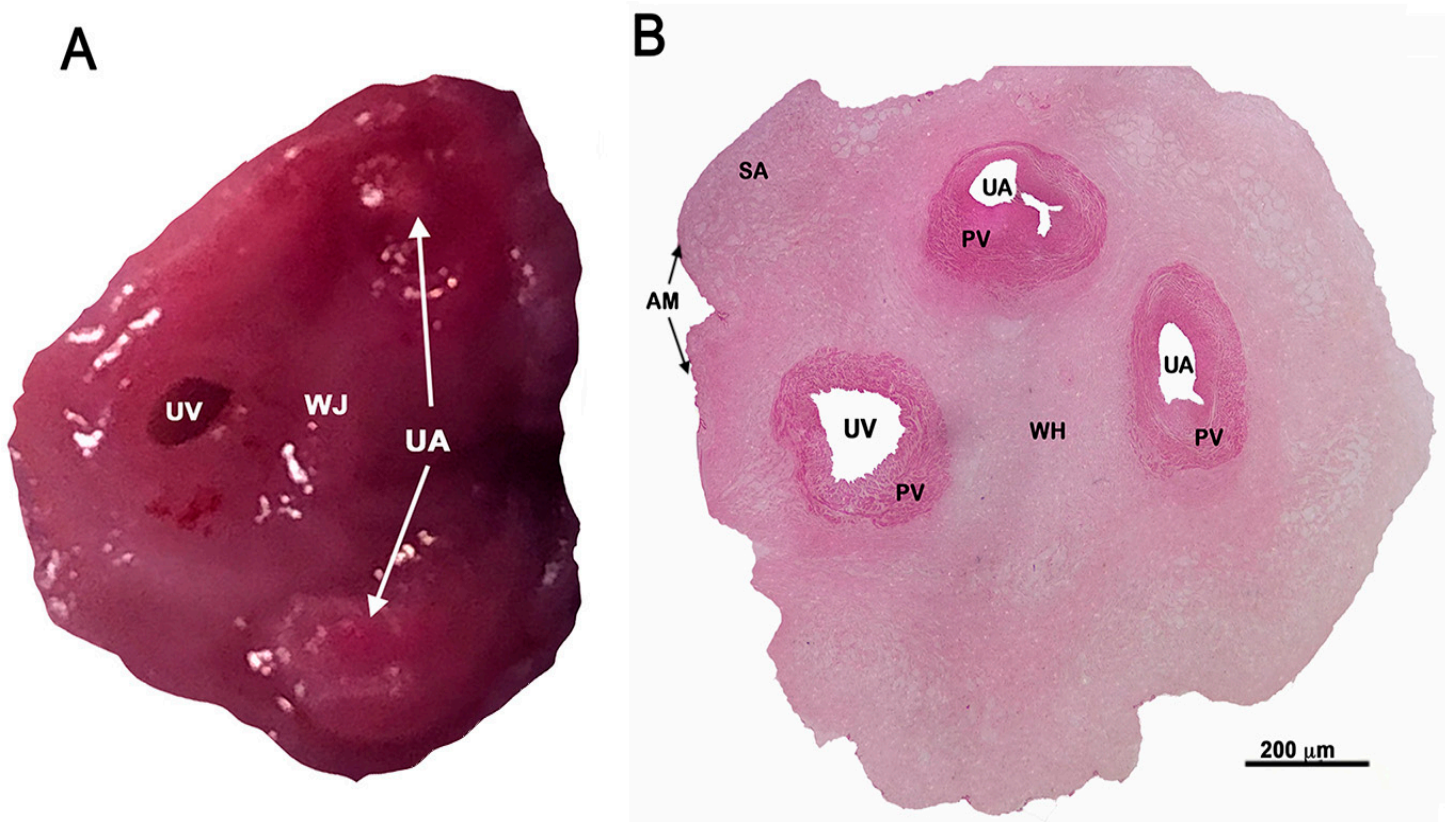

Figure 1. Representative pictures of umbilical cord. Macroscopic view (A); hematoxylin and eosin (H\&E) stained histological view (B). The two umbilical arteries (UA) and one vein (UV) are embedded in Wharton's jelly (WJ) (A). The architecture of the WJ comprises four different cell populations: Amnion (AM), Subamnion (SA), Perivascular areas (PV) and the stem cells of the WJ (WH) (B).

The human umbilical cord is compartmentalized, each compartment with distinct cellular characteristics. WJ seems to perform the function of the adventitia, which is absent from cord vessels, unifying and enclosing such vessels [20]. In situ histological cross-sections stained with Hematoxylin and Eosin (H\&E) have revealed that the architecture of the internal WJ tissue comprises four different cell populations in found defined zones: (1) The amnion (AM) located in the peripheral region, is a layer of cells that covers the umbilical cord; (2) the subamnion (SA) situated in the outermost mucous tissue, directly below the AM cells; (3) the perivascular areas (PV) surrounding umbilical blood vessels; and (4) the stem cells of the $\mathrm{WJ}(\mathrm{WH})$ located below the SA zone and between the PV and AM region (Figure 1B). The intervascular WJ region occupies the most significant area and volume of the umbilical cord [21-24].

Primitive mesenchymal stem cells are trapped in the connective tissue of the matrix, in the $\mathrm{WJ}$, and tend to migrate to the aorta-gonads-mesonephros region during embryogenesis [25]. The function of these cells in the umbilical cord is to secrete several glycoproteins, mucopolysaccharides, glycoaminoglycans and extracellular matrix proteins to form the gelatinous substance that helps prevent strangulation of vessels during pregnancy. On the other hand, the stromal cells of the umbilical cord were first recognized as "unusual fibroblasts", since they possess fibroblast-like characteristics and functions. However, several lines of evidence, such as the presence of a well-developed endoplasmic reticulum with dilated cisterns, and the presence of the prolyl-4-hydroxylase enzyme (involved with collagen synthesis), support the idea that stromal cells are responsible for the synthesis of collagen and other components of the extracellular matrix [26]. Finally, EC are distributed in the intravascular region of the cord, while epithelial cells compose the remainder tissue $[18,26]$.

\subsection{The HUVEC Model through Time}

Between 1922 and 1973, there was growing interest in HUVEC as a research model for the scientific community. Figure 2 shows a timeline of events regarding the HUVEC model, 
starting with the description of HUVEC in 1922 [27], and their isolation in 1973 by Jaffe et al. Subsequently, other milestones emerged in the study of the endothelium, implicating in vivo models. It was not until 1987, when the HUVEC model was used to study CVD and other pathological and physiological cellular events [28].

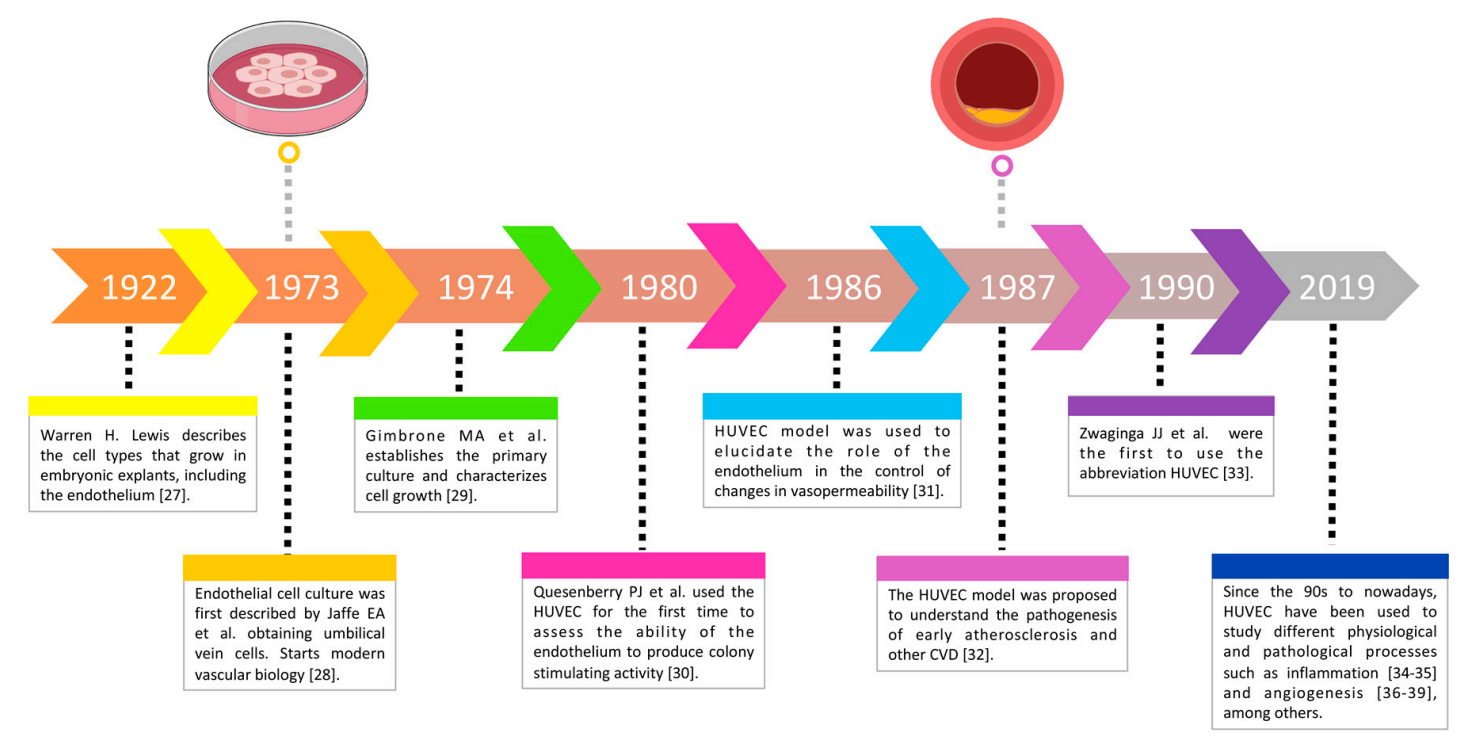

Figure 2. Timeline of human umbilical vein endothelial cell (HUVEC) cultures in science. The most important events since the first description of embryonic tissues are described, including the endothelial cell of the umbilical vein, the first isolation of HUVEC and cultures, as well as applications of the model to study cardiovascular disease (CVD) and other pathological and physiological processes [27-39].

\subsection{Isolation and Culture of HUVEC}

\subsubsection{First HUVEC Isolation Techniques}

EC cultures began in the 20th century with the work of Lewis [27] and Maruyama [40]; Eric A. Jaffe successfully isolated these cells and established the means to identify endothelial cultures by morphological, immunohistological, and serological criteria. The isolation technique established by Jaffe was as follows:

One end of the umbilical cord is cannulated with a $14 \mathrm{G}$ needle and secured with Nylon thread. Next, the vein is perfused with $100 \mathrm{~mL}$ of cord buffer (Table 1) to remove traces of blood and drain the vessel. The other end of the cord is cannulated with a $12 \mathrm{G}$ needle. The vein is then perfused with $10 \mathrm{~mL}$ of $0.2 \%$ collagenase, diluted in cord buffer, the cord is placed in a water bath with the same buffer, and incubated at $37^{\circ} \mathrm{C}$ for 15 minutes. Afterwards, the collagenase solution (containing the EC) is drained by introducing $30 \mathrm{~mL}$ of cord buffer into the vein. The effluent is collected in sterile $50 \mathrm{~mL}$ tubes containing $10 \mathrm{~mL}$ of Medium 199 (M-199) enriched with 20\% fetal bovine serum (FBS). The cells are centrifugated at $250 \mathrm{~g}$ for 10 minutes and washed with $20 \mathrm{~mL}$ of enriched M-199. Finally, the pellet is resuspended in $5 \mathrm{~mL}$ of fresh culture medium. The yield of this procedure is in the range of $0.5-1.5 \times 10^{6}$ cells per cord [28]. 
Table 1. Solutions used for umbilical cord conservation.

\begin{tabular}{|c|c|c|c|}
\hline Solution & Composition & Conservation time & References \\
\hline Cord Buffer, pH 7.4 & $\begin{array}{l}\mathrm{NaCl} 0.14 \mathrm{M} \\
\mathrm{KCl} 0.004 \mathrm{M} \\
\text { Phosphate buffer solution } 0.001 \\
\mathrm{M} \\
\text { Glucose } 0.011 \mathrm{M}\end{array}$ & $<3 \mathrm{~h}$ & [28] \\
\hline $\begin{array}{l}\text { Phosphate buffer } \\
\text { solution (cold) }\end{array}$ & $\begin{array}{l}\text { Calcium, magnesium, } \\
\text { streptomycin and penicillin. }\end{array}$ & $2-3 \mathrm{~h}$ & [41] \\
\hline Transportation buffer & $\begin{array}{l}\mathrm{NaCl} 1.4 \mathrm{M} \\
\mathrm{Na}_{2} \mathrm{HPO}_{4} 5.2 \mathrm{mM} \\
\mathrm{KCl} 40 \mathrm{mM} .\end{array}$ & $<24 \mathrm{~h}$ & [42] \\
\hline $\begin{array}{l}\text { Transportation and } \\
\text { conservation buffer }\end{array}$ & $\begin{array}{l}50 \mathrm{~mL} \text { of PBS } 1 \mathrm{X} \\
1 \mathrm{~mL} \text { of penicillin } \\
1 \mathrm{~mL} \text { of colistin }\end{array}$ & $<6 \mathrm{~h}$ & [11] \\
\hline HEPES (1X) buffer & $\begin{array}{l}\mathrm{NaCl} 137 \mathrm{mM} \\
\text { KCL } 4 \mathrm{mM} \\
\text { HEPES } 10 \mathrm{mM} \\
\text { Glucose } 11.1 \mathrm{mM} .\end{array}$ & $<3 \mathrm{~h}$ & [43] \\
\hline Supplemented PBS & $\begin{array}{l}\text { PBS supplemented with 1.5\% } \\
\text { antibiotic-antimycotic. }\end{array}$ & $<3 \mathrm{~h}$ & [44] \\
\hline
\end{tabular}

Jaffe et al. obtained EC that grew in a homogeneous monolayer of polygonal cells with poorly defined borders. In addition, morphological comparison with smooth muscle cells and fibroblasts, and Transmission Electron Microscopy (TEM) revealed that EC contain rod-shaped cytoplasmic organelles, such as those described by Weibel and Palade (Weibel-Palade bodies or WPB) in 1963 [45], absent from both fibroblasts and smooth muscle cells [28].

In 1974, Michael A Gimbrone et al. characterized the population growth behavior of primary and subcultures of HUVEC using ${ }^{3}[\mathrm{H}]$ thymidine to analyze DNA synthesis. EC cultures were found to behave as a density-dependent population with respect to DNA synthesis, useful to study cell growth and endothelial regeneration. In addition, the effluent of the umbilical vein contained small clusters of rounded cells, which adhered to the surface, was cultured and spread in the form of small epithelioid clusters within the first 2-6 hours. These agglomerations increased in size and gradually coalesced to form incomplete monolayers in 3-5 days [29]. Since 1974, reports on EC isolation emerged, aiming to study EC physiology, most based on the descriptions made by these two authors [32,41,42,46-48].

EC tend to be quiescent in vivo. However, after injury, they can change their phenotype, migrate and proliferate to heal the lesion in a few days. Much progress has been achieved, due to the culture of these cells, even though the culture process may introduce certain artifacts, cause the loss of specific functions and introduce new metabolic characteristics, which are not present in vivo [9]. For example, in vitro growth rate far exceeds in vivo rate. However, HUVEC cultures have led to many interesting findings, such as the identification of nitric oxide (NO), the relaxation factor derived from the endothelium [49].

\subsubsection{HUVEC Cultures}

Once the EC have been isolated, they should be kept in a suitable medium that allows them to grow and reach confluence, either to study metabolic functions, or to be used as an in vitro model in different investigations. Table 2 summarizes the reagents and conditions necessary for their culture, according to the most relevant reports on the subject. 
Table 2. HUVEC culture conditions.

\begin{tabular}{|c|c|c|c|c|}
\hline Culture Medium & $\begin{array}{l}\text { Additional } \\
\text { reagents }\end{array}$ & $\begin{array}{l}\text { Temperature and } \\
\text { humidity }\end{array}$ & $\begin{array}{c}\text { Periodicity of } \\
\text { change of medium }\end{array}$ & References \\
\hline TC199 & $\begin{array}{l}\text { FBS, penicillin (200 } \\
\text { U/ml), } \\
\text { streptomycin ( } 200 \\
\mu \mathrm{g} / \mathrm{mL}) \text {, } \\
\text { L-glutamine } \\
(2 \mathrm{mM}) \text {. }\end{array}$ & $37^{\circ} \mathrm{C}, 5 \% \mathrm{CO}_{2}$ & Twice a week & [28] \\
\hline M199 & $\begin{array}{l}15 \mathrm{mg} / \mathrm{L} \text { of HEPES, } \\
\text { penicillin }(60 \\
\mathrm{mg} / \mathrm{mL}), \\
\text { streptomycin }(129 \\
\mathrm{mg} / \mathrm{mL}), 20 \% \text { of } \\
\text { FBS }\end{array}$ & $37^{\circ} \mathrm{C}, 5 \% \mathrm{CO}_{2}$ & Every 48 hours & [29] \\
\hline $\begin{array}{l}\text { M199 or RPMI } \\
1640\end{array}$ & $\begin{array}{l}\text { HEPES 25mM, } 20 \% \\
\text { of FBS, L- } \\
\text { glutamine }(0.3 \\
\mathrm{mg} / \mathrm{mL}), \text { penicillin } \\
(100 \mathrm{U} / \mathrm{mL}) \text {, } \\
\text { streptomycin (100 } \\
\mu \mathrm{g} / \mathrm{mL}) \text { and } \\
\text { anti-PPLO agent } \\
(0.03 \mathrm{mg} / \mathrm{mL}) .\end{array}$ & $37^{\circ} \mathrm{C}, 5 \% \mathrm{CO}_{2}$ & Twice a week & [41] \\
\hline $\begin{array}{l}\text { Minimum } \\
\text { Essential Medium } \\
\text { Eagle }\end{array}$ & $\begin{array}{l}10 \% \text { of FBS, } \\
\text { L-glutamine }(1 \%)\end{array}$ & $37^{\circ} \mathrm{C}, 5 \% \mathrm{CO}_{2}$ & Every 72 hours & [46] \\
\hline M199 & $\begin{array}{l}20 \% \text { of FBS, } \\
\text { penicillin }(100 \mathrm{UI} / \\
\mathrm{mL}), \text { streptomycin } \\
(100 \mu \mathrm{g} / \mathrm{mL}) \mathrm{y} \\
\text { L-glutamine ( } 2 \\
\text { mM), ECGF. }\end{array}$ & $37^{\circ} \mathrm{C}, 5 \% \mathrm{CO}_{2}$ & Every 48 hours & [42] \\
\hline MCDB 131 & $\begin{array}{l}20 \% \text { of FBS, } \\
\text { penicillin and } \\
\text { streptomycin }(50 \\
\mathrm{U} / \mathrm{mL}-50 \mathrm{U} / \mathrm{mL}), 20 \\
\mu \mathrm{g} / \mathrm{mL} \text { of ECGF, } \\
\text { heparin }(16 \mathrm{U} / \mathrm{mL}) \text {. }\end{array}$ & $37^{\circ} \mathrm{C}, 5 \% \mathrm{CO}_{2}$ & Every 72 hours & {$[50]$} \\
\hline M199 & $\begin{array}{l}20 \% \text { of FBS, } 1 \mathrm{~mL} \text { of } \\
\text { penicillin-streptomycin } \\
(10,000 \mathrm{U} \text { by } 10,000 \\
\mathrm{U}) .\end{array}$ & $37^{\circ} \mathrm{C}, 5 \% \mathrm{CO}_{2}$ & Every 48 hours & [11] \\
\hline M199 & $\begin{array}{l}20 \% \text { of FBS, } 50 \mu \mathrm{g} / \\
\mathrm{mL} \text { of ECGF, } 50 \mu \mathrm{g} / \\
\mathrm{mL} \text { of heparin, } \\
\text { L-glutamine } \\
(2 \mathrm{mM}), \text { penicillin } \\
(100 \mathrm{U} / \mathrm{mL}) \text {, } \\
\text { streptomycin }(100 \\
\mu \mathrm{g} / \mathrm{mL}) \text {, } \\
\text { amphotericin (2 } \\
\mu \mathrm{g} / \mathrm{mL}) .\end{array}$ & $37^{\circ} \mathrm{C}, 5 \% \mathrm{CO}_{2}$ & Twice a week & [43] \\
\hline
\end{tabular}

Abbreviations: FBS, fetal bovine serum; $\mathrm{CO}_{2}$, carbon dioxide; HEPES, (4-(2-hydroxyethyl)-1-piperazine ethanesulfonic acid); ECGF, endothelial cell growth factor; PPLO, pleuropneumonia-like organism. 


\subsubsection{Isolation and Culture of HUVEC Conditions}

\section{Umbilical Cord Collection and Conservation}

According to different authors, umbilical cords should be collected from full-term infants, ideally delivered by natural birth, from healthy mothers, after an uncomplicated pregnancy, and should be free of hepatitis or human immunodeficiency virus (HIV) infection [42]. In some studies, the authors specify whether they used cords collected from natural births [51-53] or cesarean sections [29,54-57]. Occasionally, cords from pregnancies of mothers with certain diseases or traits may be required, for example, HUVEC from infants with mothers who developed gestational diabetes have been used for genetic, epigenetic, and proteomic studies of the effects of T2D on EC [58,59].

Although the HUC is formed during the fifth week of gestation, the bioenergetic capacity and immune response of HUVEC, obtained from preterm ( $<37$ weeks of gestation) and full-term infants (37-40 weeks of gestation), are different [60-64]. HUVEC, obtained from preterm infants, show an impaired mitochondrial bioenergy capacity, and increased production of reactive oxygen species (ROS) [64]. Illsinger et al. demonstrated that HUVEC mitochondrial enzyme activity changes lead to decreased viability of cells obtained from preterm cords [62]. In addition, the expression of selectins is lower in preterm HUVEC as compared to full-term HUVEC $[60,61,63]$. All these alterations affect endothelial function [60-64]. Therefore, it is not recommended to use HUVEC obtained from preterm infants for the study of CVD.

The cord must be collected and transported under appropriate conditions. Many authors agree that optimal storage and transportation temperature is $4^{\circ} \mathrm{C}$. Moreover, best results are obtained when the umbilical cords are processed between 10 and 24 hours after collection [32,42], although comparable success rates have been obtained when umbilical cords are processed up to 48 hours after birth [65]. One of the first tissue conservation studies was carried out in 1949 by Peirce et al., who reported that refrigerated tissues retain their viability for a certain time, depending on the type of tissue, size, oxygen availability, storage temperature and other factors [66]. Lower temperatures decreased the demand for oxygen; thus, tissues preserved at $0^{\circ} \mathrm{C}$ were able to survive for a certain period of time in oxygen-deprivation conditions. Other studies have reported that different tissues can be conserved in Ringer's solution or saline solution at temperatures between $3^{\circ} \mathrm{C}$ to $6^{\circ} \mathrm{C}$. The preservation of blood vessels in serum or blood is also satisfactory for short periods of time; the ideal preservation medium must contain physiological concentrations of salts, buffer, glucose and small accessory molecules present in serum [50]. Finally, umbilical cord length is a parameter to consider, as some authors suggest the cord should be discarded if it is shorter than $12 \mathrm{~cm}$ in length or has damaged areas, as this could result in a low number of isolated cells. Similarly, if the cord has clots, it is recommended not to force them out and to cut the affected section [66].

\section{HUVEC Culture Considerations}

HUVEC culture success depends on many factors. According to Gimbrone et al., one-third of 200 processed cords failed to reach confluent densities, and growth initiation seems to be related to the presence of multicellular aggregates in the venous effluent [29]. Various factors may decrease HUVEC viability and lead to culture failure. In this sense, Marin et al. proposed some recommendations before HUVEC isolation [42]:

a) Heat the sterile transport buffer in a water bath at $37^{\circ} \mathrm{C}$. This will prevent thermal shock disabling cell growth.

b) Prepare a sterile area in a laminar flow hood. This will prevent bacterial and fungal contamination of both reagents and cultures.

c) Before starting the isolation procedure, it is desirable to identify the human umbilical vein. Umbilical arteries are more rigid and difficult to dilate (Figure 1A,B).

d) It is recommended to store collagenase in $10-12 \mathrm{~mL}$ aliquots at $-20^{\circ} \mathrm{C}$ to avoid denaturation. 
e) The culture flasks must be previously covered with gelatin or fibronectin to ensure cell adhesion.

The culture medium supplies amino acids used for protein synthesis in cell culture. The most used medium is M199 (Table 2). However, MCDB 131 medium with high levels of magnesium $(10 \mathrm{mM})$ increases cell proliferation two to three-fold, as compared to M199 medium $(1.6 \mathrm{mM})$. Artificial media containing growth factors are also efficient [42]. The use of enriched media, such as M199 or Dulbecco-Vogt medium is ideal for promoting cell growth, but glutamine deficient media or minimum essential medium of Eagle are not suitable for the cultivation of HUVEC [42]. HUVEC can survive in an FBS-free medium for up to $12 \mathrm{~h}$ without losing their phenotypic characteristics. However, in experiments taking longer than 24 hours, the absence of growth factors promotes apoptosis. This can be avoided by using an enriched medium, but with a low concentration of proteins, such as the commercial medium Ultroser G at 1\% in M199 without FBS where HUVEC can survive for $48 \mathrm{~h}$ [29]. For optimal growth, freshly isolated cells require medium supplemented with $20-30 \%$ of FBS, although $10 \% \mathrm{FBS}$ is sufficient to maintain the growth density of primary cultures and subcultures [11].

Vascular endothelial growth factor (VEGF) or vasculotropin supplementation stimulates the selective growth of EC in serum-free medium. To date, it is the only EC-specific growth factor. VEGF is an angiogenic growth factor, stable to heat and acidic environment, belonging to a small family of chemically similar dimeric heparin-binding glycoproteins with an approximate molecular weight of $46 \mathrm{kD}$ [67]. This factor is essential in the development and formation of blood vessels in mammals, both in normal and pathological conditions. It is a highly selective and potent mitogen for EC [49]. The concentration of FBS and growth factors can modify the synthesis of some EC molecules; particularly, progressive deprivation of FBS decreases the secretion of IL-8 into the medium [42].

Heparin, a sulfated mucopolysaccharide, increases EC proliferation in the presence of heparin-binding growth factors, such as endothelial cell growth factor (ECGF) [42]. In 1983 heparin was used for the first time in culture to enhance the stimulatory effect of ECGF for HUVEC proliferation. It is likely that heparin binds to the cell surface, where it facilitates intracellular communication and accessibility to membrane receptors [68]. Heparin concentrations used in HUVEC cultures vary from $10 \mu \mathrm{g} / \mathrm{mL}$ to $90 \mu \mathrm{g} / \mathrm{mL}[35,43,50,59,68-71]$.

Finally, the use of fibronectin or gelatin in the culture is very important because it enhances cell adhesion, while ECGF supplementation and serum-enriched medium allow long-term growth. Under these conditions, it was possible to perform 15 to 21 passages before HUVEC became quiescent, while cultures without these elements ceased their growth after the second passage [72].

\subsection{Advantages and Disadvantages of the HUVEC Model}

An in vitro model must be accessible, easy to handle, reproducible and in accordance with an appropriate ethical framework. It must also reproduce the pathophysiology of the human disease to be studied as accurately as possible. In this sense, HUVEC more faithfully represents human EC behavior as compared to cell lines [73]. The HUVEC model is physiologically representative of the human vascular endothelium, allowing the study of the physiological and pathological effects of different stimuli both in an isolated form, and in co-culture with other cell types, such as leukocytes and smooth muscle cells [72]. It is also useful to study the effects of novel drugs on human endothelium [74]. Moreover, a recent innovation in gene editing provides the opportunity to study the effects of specific mutations in EC [1,34]. Most importantly, the HUVEC model has been useful to study a broad array of biological processes and diseases, such as inflammation, apoptosis, preeclampsia, cancer, CVD and regenerative medicine $[12,13,49,58]$.

Among technical advantages, cultured HUVEC are subject to contact inhibition and limitations in growth density, as cell proliferation is strongly inhibited once the culture has reached confluence [75]. Moreover, because different components of the extracellular matrix can promote the formation of capillary-like structures in HUVEC cultures, they are useful as angiogenesis models, although they do not reflect all the steps of physiological angiogenesis. These models are simple, particularly suitable for in vitro screening of angiostatic molecule activity and can also be used to evaluate the ultrastructure of 
capillary formation, matrix synthesis of EC or the role of adhesion molecules in the process of tubular morphogenesis. They are also useful to functionally characterize EC lines, to study the putative role of adhesion molecules (such as E-selectin, platelet endothelial cell adhesion molecule [PECAM-1], cadherin- 5 and proteases), the synthesis of extracellular proteins and blood vessel maturation [37].

Because the HUC is fetal and not maternal tissue, gender differences must be considered. Umbilical cord cells are subject to the effect of hormones produced by the fetal gonad in addition to maternal hormones. In fact, various studies have shown gender differences in male and female umbilical cords regarding gene expression, protein expression, cell viability after serum starvation, tube formation capacity, autophagy, intracellular ATP and metabolite levels, oxidative stress and angiogenesis [76-79]. Sexual dimorphism shown by HUVEC indicates that sex differences exist in prenatal life and are parameter-specific, suggesting that HUVEC of both sexes should be used as a model to increase the quality and the translational value of research. The sex differences observed in HUVEC could be relevant in explaining the adulthood diseases because endothelial dysfunction has a crucial role in the pathogenesis of diabetes mellitus, cardiovascular, neurodegenerative and immune disease [76]. Among possible disadvantages, while it was initially assumed that EC were homogeneous, it is now known that vascular cells show a high degree of heterogeneity, allowing biological adaptation to local needs [80]. In addition, the EC growth rate is much higher in vitro than in vivo; although this can be controlled using inhibitors and growth factors to make them quiescent [49]. Finally, the lifespan of HUVEC is approximately 10 passages, although some authors affirm that these cells lose their primary characteristics and ability to respond to stimuli after passage 6 . Although HUVEC can be maintained in culture for up to five months, one of their main disadvantages is that they are not suitable for long-term experiments [75].

\section{HUVEC Identification}

The vascular endothelium is characterized by heterogeneity of morphological and functional aspects, cell activation marker proteins and response to growth factors.

\subsection{Morphological Description}

The morphology of HUVEC was first characterized by Jaffe in 1973. After five days of culture, EC grew, forming a monolayer with a poorly defined spiral pattern. The cells were homogeneous, closely opposite, long and polygonal with an oval nucleus in the center. Contrast microscopy revealed that the cell borders were different, and in some areas, interdigitations connecting separated cells appeared. TEM observations showed homogeneous flat cells, $30 \times 50 \mu \mathrm{m}$ in size, that grew in a monolayer with varied edges and prominent nuclei. EC observed by TEM in situ in the umbilical cord vein, were thin and flat with pinocytic vesicles and several cytoplasmic vesicles. The cytoplasm also contained clusters of free ribosomes, smooth and rough endoplasmic reticulum, agglomerations of fine filaments and prominent microtubules [28]. Additionally, the cytoplasm of these cells contained numerous oval rod-shaped bodies, described previously by Weibel and Palade (WPB) [45]. HUVEC form a uniform monolayer of polygonal cells in approximately one week. They are characterized as EC by the presence of WPB, pinocytic vesicles, small amounts of $100 \AA$ fibrils located near the nucleus, mitochondria with tubular shapes which rarely showed ramifications, an ellipsoid nucleus with a fine granular pattern of condensed chromatin and one to three nucleoli present in each nucleus [81]. As primary EC cultures grow and expand, cell-cell contacts are created and always appear circumscribed by a basement membrane layer. After three to four weeks, the cells acquire their typical endothelium form in a confluent monolayer, that is, in a hexagonal or cuboidal form with long, round and slightly overlapping nuclei (Figure 3). If the cells remain in confluence, the monolayer decreases and elongated rather than cuboidal cells are observed [82]. Other exclusive ultrastructures found in EC are prominent nucleoli, perinuclear regions rich in mitochondria, endoplasmic reticulum and Golgi complexes, micropinocytic vesicles and the presence of abundant microfilaments in the cytoplasm [29]. 
The peripheral cytoplasm shows complex interdigitations with adjacent cells, often forming small spaces in cross-sections [82].

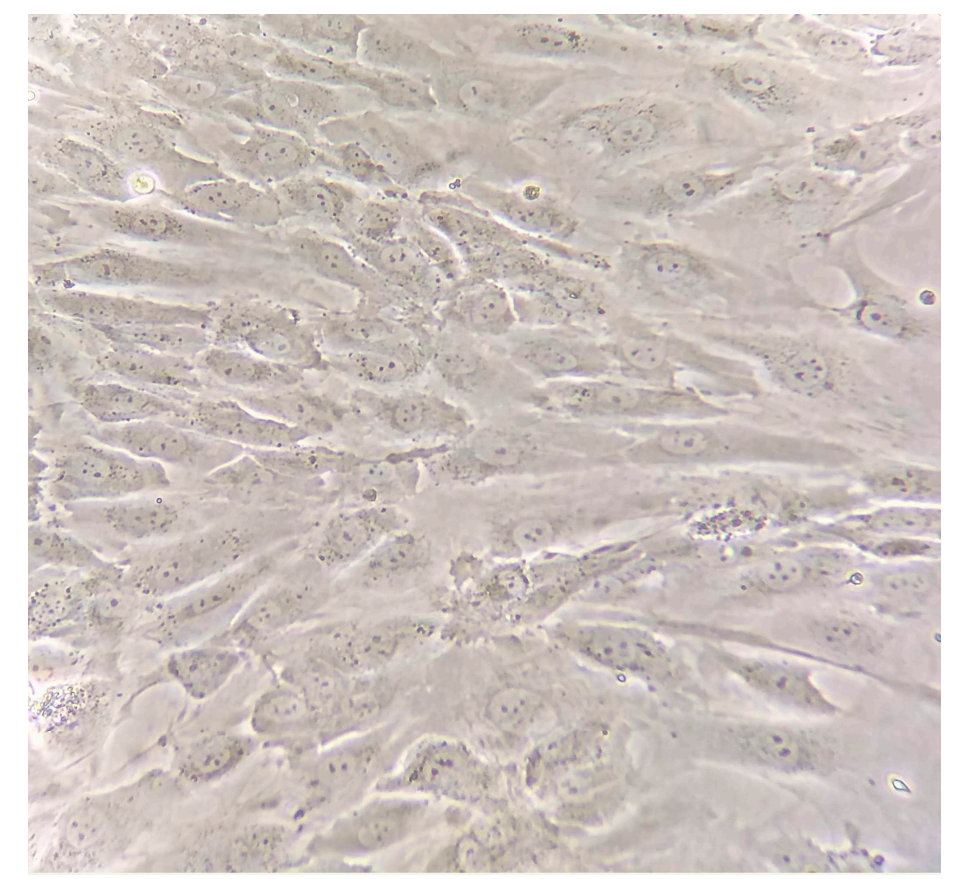

Figure 3. Microscopy view of HUVEC. 40X. The photomicrograph shows the morphological characteristics of endothelial cells (EC) from the human umbilical vein. A confluent monolayer in a hexagonal or cuboidal form with large nuclei is observed.

The WPB are ovoid rod-shaped granules, with a membrane containing parallel arrangements of 6-26 tubular structures, of approximately $150 \AA$ width. These are deposit organelles for factor VIII, rarely found in microcapillaries. The density of WPB in EC decreases depending on the distance from the heart [49]. These structures are used to identify cultured cells as endothelium, since these organelles have not been found in fibroblasts or smooth muscle cells [29].

EC have also been described as confluent cobblestone-shaped layers [11,49], simulating the morphology of the endothelium in vivo. When the culture has been maintained for long periods of time, the monolayer begins to disorganize. Likewise, cobblestone morphology can also be affected by exposure to a dynamic flow [11]. Thus, shear stress can induce elongation of the cells in the flow direction. Another important feature of EC is their ability to form capillary-like structures when placed in a Matrigel matrix, fibrin or collagen, and stimulated with serum or growth factors $[49,83]$.

Even though EC show numerous morphological characteristics, EC identification cannot be achieved by optic microscopy examination alone. WPB can be identified only by electron microscopy, and are often difficult to locate, so the identification of other factors mentioned below is suggested.

\subsection{Cellular Markers}

Different cell markers can be identified in the cytoplasm or EC membrane. Some are expressed in all EC, such as CD31 and factor VIII (Figure 4), while others are tissue-specific. The most relevant EC markers are described below. 


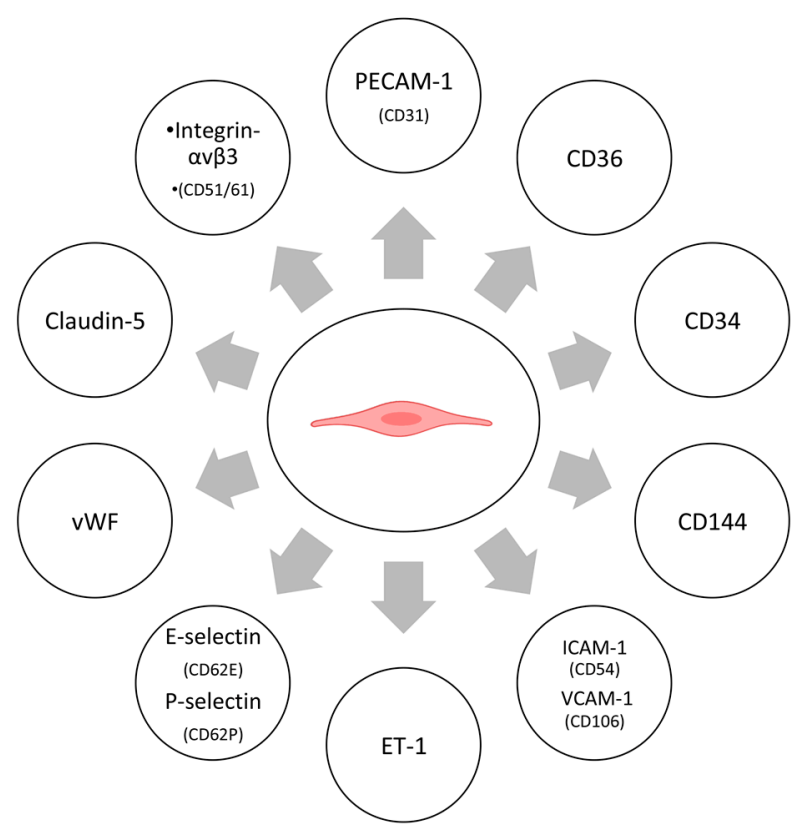

Figure 4. Protein markers in HUVEC. Schematic illustration shows the protein markers that can be identified in HUVEC using antibodies.

\subsubsection{Protein Markers}

Platelet endothelial cell adhesion molecule (PECAM-1, endoCAM or CD31). CD31 is a glycoprotein of the immunoglobulin (Ig) superfamily. This protein is found in the EC membrane, near the intercellular junctions. Its main function is to regulate the EC-EC and EC-leukocyte adhesion [84]. It is a universal endothelial marker, used for microcapillary count in tumor samples [49]. However, CD31 can also be expressed by monocytes and some leukocyte populations [85]. It can be identified by flow cytometry or by immunofluorescence $[86,87]$.

CD36. Also known as platelet glycoprotein IV, this receptor is an $88 \mathrm{kD}$ transmembrane glycoprotein with a large extracellular domain and serves as an adhesion receptor for thrombospondin-1, among others. Originally found in platelets and monocytes, it is also expressed in microvascular cells, but not in large capillary vessels [88,89]. Likewise, it has been identified not only in the endothelium, but also in monocytes and certain types of epidermal cells [89].

CD34. The CD34 human progenitor cell antigen is a $115 \mathrm{kD}$ monomeric glycoprotein that is selectively expressed in hematopoietic progenitor cells of the spinal cord, EC, and in numerous non-hematopoietic tissues, including skin [90], leukemic cells and stem cells [91]. Several studies have described the expression of CD34 in EC of capillaries, arteries, veins, arterioles and venules, as well as in smooth muscle cells of the aorta and some fibroblasts. This marker is commonly used to identify EC by immunohistochemistry [49,91].

CD144. Also known as VE-cadherin, it belongs to a group of transmembrane glycoproteins that promote calcium-dependent cell-cell hemophilic contact. VE-cadherin is specifically found at interendothelial junctions [92], necessary for vascular genesis and repair of vascular disease [93]. This protein is also used as an endothelium marker [49], guarantees the maturity of the cell-cell junctions and the homogeneity of HUVEC [57].

Intercellular adhesion molecule 1 (ICAM-1) and Vascular cell adhesion molecule 1 (VCAM-1). Both molecules are members of the immunoglobulin superfamily and are involved in EC adhesion. ICAM-1 mediates leukocyte adhesion to the endothelium via lymphocyte function-associated antigen 1 (LFA-1), and to monocytes and neutrophils via macrophage-1 antigen (Mac-1). VCAM-1 mediates adhesion of mononuclear cells to the endothelium via two ligands of the integrin family, called integrin- $\alpha 4 \beta 1$ and activated integrin- $\alpha 4 \beta 7$ (or VLA-4) [94]. These endothelial markers can be identified using monoclonal antibodies: Anti-CD54 for ICAM-1 and anti- CD106 for VCAM-1 [11,49,95]. 
Endothelin-1 (ET-1). ET-1 is a potent vasoconstrictor peptide with both paracrine and local effects. ET1 levels have been found to be increased in certain pathological conditions, such as hypertension, uremia and cardiogenic shock [96]. It is the only endothelin produced by EC. ET-1 immunoreactivity is detected in EC supernatants by radioimmunoassay or by enzyme-linked immunoabsorption assay (ELISA) [49].

E-selectin and P-selectin ( $E$ and $P$ ). E and P selectins are adhesion molecules found in EC. They belong to the family of calcium-dependent lectins responsible for supporting initial leukocyte adhesion and extravasation through carbohydrate recognition [97], and mediating leukocyte adhesion under conditions of shear stress [98]. Adhesion is mediated by the expression of integrins in leukocytes and carbohydrate-containing counter-receptors expressed by EC [84]. E-selectin, considered a cell activation marker, mediates the initial low affinity interaction between leukocytes and the vascular endothelium, a process known as rolling. This protein is expressed exclusively in EC when stimulated with inflammatory cytokines [97]; however, it can promote the adhesion of leukocytes on multiple cell types [99]. P-selectin mediates the formation of activated platelet rosettes on leukocytes [98].

Factor VIII antigen or von Willebrand Factor ( $v W F$ ). Factor VIII antigen is perinuclear and has been associated with WPB. The VWF is synthesized by vascular EC and is considered as a specific endothelial marker. It is normally expressed in EC, although expression is dramatically reduced in damaged vascular cells $[49,93]$. vWF expression tends to decrease with each passage, reaching a staining percentage of $93 \%, 77 \%$ and $63 \%$ in passages 3,9 , and 11 , respectively. vWF detected by immunohistochemistry can be used for EC identification, and to check junctional maturity and HUVEC homogeneity $[57,84]$.

Claudin-5. EC express VE-cadherin at adherent junctions and claudin-5 at tight junctions. Claudin- 5 mediated adhesion is independent of calcium. It is a marker for other EC, such as endothelial dermal cells of the microvasculature [100]. Claudin- 5 can be detected by immunofluorescence microscopy [101].

Integrin $\alpha_{v} \beta_{3}$. Integrin $\alpha v \beta 3$ is a receptor for extracellular matrix proteins, such as vitronectin, fibronectin and $\mathrm{vWF}$, expressed in EC. It is considered as a marker of angiogenesis [88], and its main action is to maintain the integrity of the blood vessel wall. This protein can be identified by flow cytometry using CD51/61 monoclonal antibodies [84].

\subsubsection{Enzymes}

Angiotensin-converting enzyme ( $A C E$ ). This enzyme catalyzes the conversion of angiotensin I into the vasoactive angiotensin II peptide and is responsible for bradykinin catabolism. The presence of this enzyme can be demonstrated by indirect immunofluorescence microscopy. In addition, its enzymatic activity can be measured in conditioned media, using chromogenic or fluorogenic substrates [49].

Endothelial nitric-oxide synthase (eNOS). The expression of the constitutive endothelial form of nitric-oxide synthase (eNOS) can be monitored at different levels: (a) at the gene level by RT-PCR; (b) at the protein level by immunohistochemistry in subconfluent monolayers; and (c) by Western blot in cell lysates. Basal eNOS activity and activity in response to specific stimuli with bradykinin, substance $\mathrm{P}$ or VEGF, can be evaluated by the conversion of L-[3H]-arginine into L-[3H]-citrulline, both in cell lysates and in subconfluent monolayers, or by measuring nitrite accumulation in supernatant [49].

\subsubsection{Other Markers}

ABH antigens. EC contain $\mathrm{ABH}$ antigens specific to the donor's blood type tissue, while connective tissue and smooth muscle lack this antigen system. The agglutinin of a plant called Ulex europaeus is used to identify these antigens [11]. HUVEC express the $\mathrm{H}$ antigen, whereas, smooth muscle cells and fibroblasts lack this antigen system [28].

Dil-conjugated acetylated low-density lipoproteins (Dil-Ac-LDL). In this assay, cells are incubated in the presence of acetylated low-density lipoproteins (Ac-LDL), where uptake is monitored by fluorescence microscopy. This technique can be used to verify the presence of endothelium, but not of vascular smooth muscle cells. This marker is constitutive, and can be modulated in vitro, depending on 
confluence state of the culture [11,49]. The lipoproteins are labeled with a fluorescent probe containing the compound 1,1'-dioctadecyl-3,3,3',3'-tetramethyl-indocarbocyanine perchlorate or Dil, a highly lipophilic molecule that can be incorporated non-covalently in lipoproteins. Once a lipoprotein containing Dil is assimilated by a cell, the probe accumulates in lysosomal membranes [102]. The advantage of using LDL metabolism as a marker is that viable EC can be labeled, without the need to fix or permeabilize these cells [93].

Prostacyclin release (PGI2). Prostaglandins are products of the arachidonic acid metabolic pathway, synthesized by various tissues, including vascular EC. PGI2 is a potent vasodilator that relaxes the vascular tone of smooth muscle in arteriolar terminals [103]. Prostaglandins are involved in acute inflammation binding G proteins [104]. The production and release of PGI2 in HUVEC culture supernatant can be measured by commercial radioimmunoassay kits, such as 6-keto-prostaglandin F1 $\alpha$ (6-keto PGF1 $\alpha)[49]$.

Tube-formation assay. The Matrigel basement membrane is a solubilized extract of the extracellular matrix of Engelbreth-Holm-Swarm (EHS) sarcoma [105]. It has two main components: Laminin and type IV collagen, but also contains proteoglycans with heparan sulfate chains, entactin (nidogen-1) and some other minor components. The Matrigel is used to form a substrate or a three-dimensional gel, in which the EC form tubules that simulate the microanatomic cellular relationships that are generated in vivo [67]. This assay is used to assess the angiogenic capacity of the EC by the formation of tubular structures using different microscopy techniques, such as digital microscopy in low power fields [53], fluorescence microscopy [93], inverted microscopy [106,107], and reverse phase contrast microscopy [108].

\section{HUVEC Model Applications}

Thorough understanding of human physiological and pathological conditions requires the use of different experimental models. The HUVEC model can better represent some aspects of human disease as compared to animal models. The most relevant HUVEC model applications in cardiovascular and metabolic diseases are described below (Figure 5).

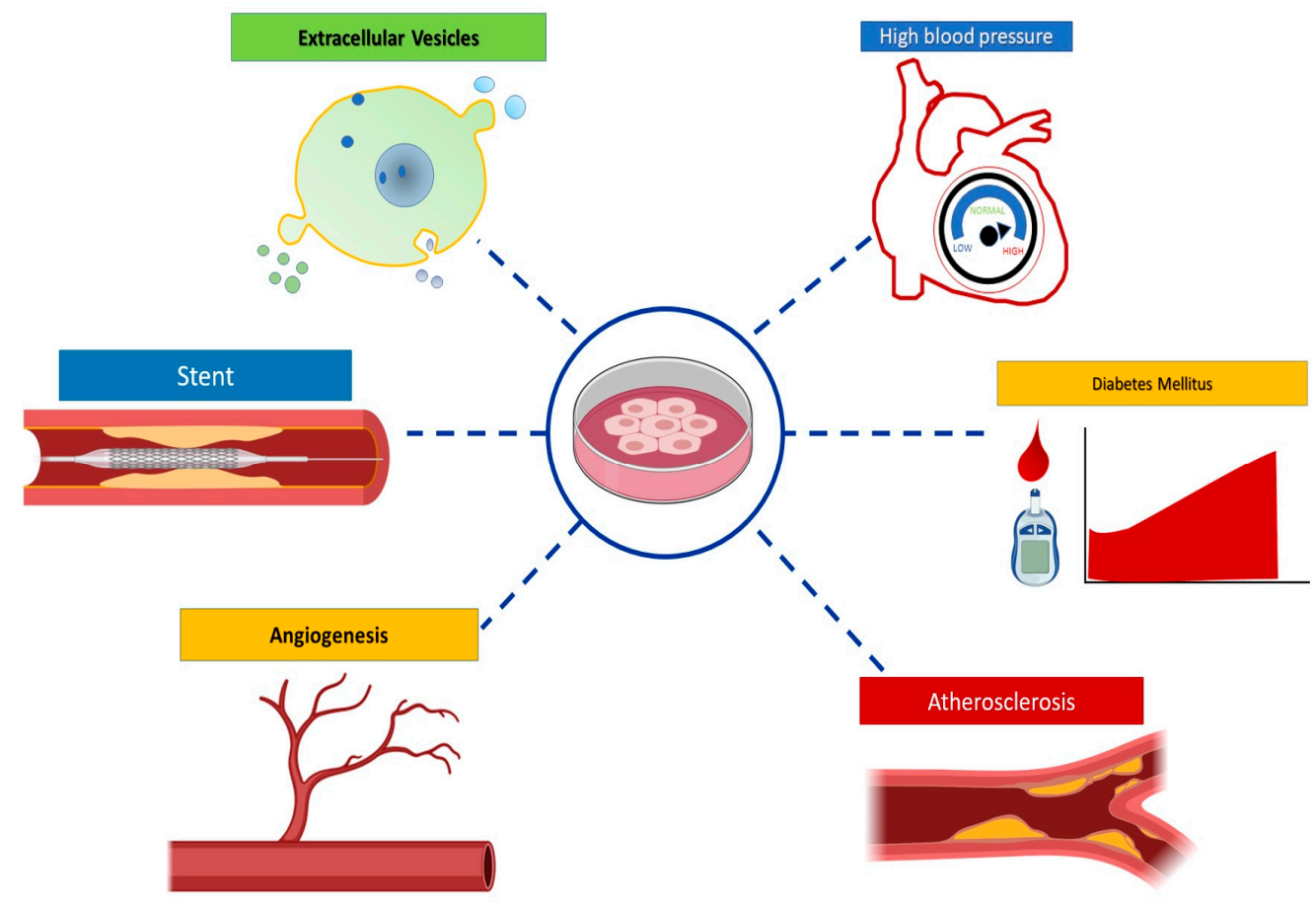

Figure 5. Applications of HUVEC models to study cardiometabolic disease. 


\subsection{Cardiovascular and Metabolic Diseases}

CVD are the leading cause of death in the world. These diseases affect the structure and/or function of the heart and blood vessels, and include highly prevalent disorders such as hypertension, atherosclerosis and myocardial infarction, among others $[1,4,109,110]$. Several metabolic risk factors involved in the development of CVD, such as hypercholesterolemia and diabetes promote EC dysfunction $[4,109,111]$

\subsubsection{Hypertension}

Hypertension is a chronic and multifactorial disease [1]. In recent years, its incidence has increased, and onset occurs at earlier ages. This disease induces endothelial dysfunction by decreasing the secretion of $\mathrm{NO}$ and endothelin in EC, which causes arterial vasoconstriction and favors apoptosis [74,112]. Although there has recently been great progress on the knowledge of hypertension, the molecular mechanisms underlying endothelial injury are not fully understood. Some relevant findings achieved in HUVEC models are described below.

MicroRNAs are short non-coding RNAs that regulate gene expression at the post-transcriptional level by binding to sequences in the 3'UTR region of their target mRNA [112-114]. In a recent study, patients with hypertension showed increased microRNA-34a expression in peripheral blood as compared to controls [115]. MicroRNA-34a inhibition in HUVEC promoted proliferation, migration, and G1-S transition of EC. Bioinformatic analyses predicted that mRNA of the transforming growth factor $\beta$-induced factor homeobox 2 (Tgif2) is a microRNA34-a target, suggesting the potential use of microRNA-34a as a diagnostic biomarker [112].

Zofenoprilat is known to inhibit the action of the angiotensin-converting enzyme, a therapeutic target in CVD. Using a HUVEC model, Monti et al. demonstrated that this drug also induces $\mathrm{H}_{2} \mathrm{~S}$ production and decreases the expression of proinflammatory genes involved in the recruitment of inflammatory cells and platelets in the vascular endothelium. The authors conclude that zofenoprilat exerts a protective effect for the endothelium by multiple complementary mechanisms, thus, proposing this drug as one of the first choices for treatment of CVD [74].

Finally, HUVEC models have been very useful to evaluate the protective effect of several drugs on the endothelium, such as sodium nitroprusside [116], safflor yellow B [117], resveratrol, piceatannol, and astringin [118], and have been useful to create new therapeutic and prevention strategies [116-118].

\subsubsection{Atherosclerosis}

Atherosclerosis is a chronic inflammatory disease characterized by the accumulation of low-density lipoproteins (LDL) and immune cells in the subendothelium, resulting in the formation of an atherosclerotic plaque. At early stages, morphological changes in the endothelium can be regulated by interaction with hemodynamic forces $[2,3,111,119]$. The distribution of blood flow in different arterial regions produces shear stress (SS): High laminar and constant (LSS) and oscillatory and low (OSS). The first induces an atheroprotective phenotype in the EC, while the latter confers a pro-atherogenic phenotype $[2,5,111,120,121]$. The expression of atherosclerosis-related genes can be downregulated or upregulated, depending on the type of flow $[120,122,123]$.

Sheikh et al. developed a system using the HUVEC model to study the effect of SS, since these cells can recruit different types of leukocytes in response to stimulation with tumor necrosis factor alpha (TNF- $\alpha$ ). An advantage of the system is the ability to grow multiple samples in parallel and expose the EC to different flow types [124].

The ATP-Binding Cassette Transporter A1 (ABCA1) transporter is a transmembrane protein with flopase activity. This activity transfers phospholipid phosphatidylserine (PS) from the inner to the outer membrane layer in response to activation stimuli or cellular stress. These mechanisms are essential for microvesicle (MV) biogenesis. Vion et al. demonstrated that LSS decreases endothelial-derived 
MV (EMV) formation in HUVEC. This decrease results from endogenous NO release and ABCA1 expression downregulation. OSS has an opposite effect, causing loss of phospholipid asymmetry in the membrane increasing EMV production. EMVs have been proposed as biomarkers of endothelial dysfunction, and high EMV plasmatic concentrations are associated with CVD [5].

SS regulates the expression of different genes, for example, the HoxB9 gene. It has been reported that HoxB9 gene expression is induced by OSS in HUVEC [122]. Finally, HUVEC cultures have been used to study the pro- and anti-atherogenic effect of several molecules, such as arsenic and saikosaponin, in the early stages of atherosclerosis $[125,126]$.

\subsubsection{Hypercholesterolemia}

Hypercholesterolemia is considered one of the main risk factors for the development of atherosclerosis $[2,6,119,127,128]$. The atherogenic endothelial phenotype has higher permeability to circulating LDL. Oxidized LDL accumulate in the subendothelial space and initiate a local inflammatory response $[2,3,6,119,128]$.

HUVEC models have been useful for the identification of new biological markers associated with hyperlipidemic-induced damage, attempting to achieve early diagnosis [6,128-130]. HUVEC models have also been useful to identify therapeutic targets, such as microRNA 338-3p. In pathological conditions, microRNA 338-3p induces apoptosis. It decreases EC viability by binding to the BAMBI mRNA (BMP and activin receptor membrane-bound inhibitor), a pseudoreceptor that acts as a TGF- $\beta$ signaling pathway inhibitor [6].

\subsubsection{Diabetes Mellitus}

Diabetes Mellitus (DM) is a heterogeneous disorder characterized by a loss in glucose homeostasis and insulin resistance [131]. DM is a CV risk factor, and hyperglycemia is associated with chronic endothelium inflammation and endothelial dysfunction [132-137].

HUVEC models have been used to study the molecular mechanisms involved in EC damage induced by high glucose concentrations. Hyperglycemia has been shown to decrease NO synthesis, to activate proinflammatory signaling pathways [138-140], to induce changes in the protein expression profile [141], and to increase the production of ROS [142], leading to apoptosis and endothelial dysfunction [143]. In contrast, decreasing glucose levels is not enough to turn off the intracellular pro-oxidant environment; this persistence is called metabolic memory [135].

The use of oral hypoglycemic agents, such as teneligliptin reduces ROS production and induces overexpression of antioxidant genes. This drug can counteract the apoptotic phenotype and restore proliferative properties [135]. Other compounds with the same features, such as osthol [144] and phosphocreatinin [145] have been studied, and have shown similar effects and benefits. Moreover, high-density lipoproteins (HDL) [136] and microRNA-199a-3p [137] promote EC proliferation and migration under hyperglycemic conditions, activating different signaling pathways and promoting repair of the damaged vascular endothelium. These findings suggest that HDL and microRNA-199a-3p may be considered as potential therapeutic targets $[136,137]$.

\subsection{Angiogenesis}

Angiogenesis is a hallmark of repair, expansion, and remodeling in physiological and pathological conditions. This process includes EC activation, migration, and proliferation that ends with the formation and organization of tubular structures to form new blood vessels [113,146,147]. This mechanism plays an essential role in vascular remodeling during ischemic events [148]. Because the growth of collateral vessels offers an alternative route for irrigation when a coronary artery is blocked, angiogenesis may decrease myocardial damage and improve prognosis [149]. HUVEC models have been used to study the molecular and signaling pathways involved in this process [150-154]. Pro-angiogenic factors are known as potential therapeutic agents to treat ischemic heart disease and protect EC in the arteries [108,150-156]. 
Voellenkle et al. identified 400 microRNAs differentially expressed in HUVEC associated with angiogenesis under hypoxic conditions [157]. MicroRNA-939 is negatively regulated in patients with coronary artery disease, and this reduced expression is associated with increased coronary collateral circulation [149]. The authors suggest these microRNAs are potential biomarkers and therapeutic targets in ischemic heart disease.

Finally, HUVEC models have been used to assess the pro-angiogenic effect of proteins, such as irisin [108], and drugs, such as Evolocumab [148], metformin [155], and cilostazol [156] which may offer additional therapeutic benefits in CVD.

\subsection{Other applications}

\subsubsection{Extracellular Vesicles}

Extracellular vesicles (EVs) are anuclear vesicles surrounded by a membrane, classified according to biogenesis and size. Based on size, EVs can be classified as exosomes (40-100 nm), microvesicles $(100 \mathrm{~nm}-1 \mu \mathrm{m})$, or apoptotic bodies $(>1 \mu \mathrm{m})$ [158-160]. EVs have been proposed as vectors of intercellular communication, with important roles under physiological and pathological conditions, including CVD. EVs transport bioactive molecules, such as proteins, lipids, and nucleic acids that can regulate different cellular processes and signaling pathways [159-162].

HUVEC have been used to evaluate how different stress conditions affect EVs composition, production, or content, as well as their communication with other endothelial or other cell types [5,161-164]. HUVEC exposed to high glucose concentrations increased EMV production and induced changes in their composition and functionality $[162,165]$, contributing to endothelial dysfunction development and progression. Moreover, TNF- $\alpha$ stimulation of HUVEC caused changes in EVs protein [163,166-169], and microRNA expression [168-170]. These changes induced functional alterations in the recipient cells, suggesting that EC-derived EVs have a vital mediator role in CV homeostasis [140,163-170].

\subsubsection{Stent Use}

Stents are prostheses with antithrombotic and antiproliferative properties, that can be inserted in narrowed coronary arteries promoting the regeneration of healthy endothelium. They are used as an alternative treatment for coronary artery obstruction. However, the two main complications of stent implantation are restenosis and thrombosis $[110,171,172]$. HUVEC models have been used to explore ways to prevent these complications.

Tirofiban was found to improve EC migration and proliferation in bioabsorbable stents using a HUVEC endothelial model [172]. Several studies in the HUVEC model have shown that coating stents with other polymers can reduce the risk of complications [173-175]. Beshchasna et al., reported that HUVEC incubated with titanium oxynitride (TiOxNy) coated discs showed lower metabolic activity after $48 \mathrm{hrs}$ as compared to HUVEC treated with uncoated discs. They also reported that stents covered with TiOxNy have a lower rate of deposition of salts and albumin; stating that this compound is highly recommended for that purpose [174]. Finally, Yang et al., proposed that organoselenium compounds generate NO in a HUVEC model. Coating stents with this bioactive compound provided a microenvironment capable of mimicking the endothelium and promoting endothelial recovery of the luminal surface of the stent [175].

\section{Conclusions}

The isolation and characterization of HUVEC, and HUVEC-based models have transformed vascular biology achieving very significant advances in various fields of science. HUVEC as a model to study the endothelium has greatly facilitated the study of CVD. Although HUVEC studies do not replace animal models, they offer advantages and benefits in basic research and in the development of new therapies and diagnostic methods. 
Author Contributions: The idea of the present review was conceived by L.J.-A.; D.J.M.-L., M.D.-P., I.M. and L.J.A. wrote and prepared the original draft; M.T.V.-M. reviewed and edited the manuscript. All authors have read and agreed to the published version of the manuscript.

Funding: This research received no external funding.

Acknowledgments: We thank Belem Gabiño López and Ricardo Nava Monroy for their assistance in the hematoxylin and eosin (H\&E) staining of the histological cut of the umbilical cord.

Conflicts of Interest: The authors declare no conflict of interest.

\section{References}

1. Soler-Botija, C.; Galvez-Monton, C.; Bayes-Genis, A. Epigenetic Biomarkers in Cardiovascular Diseases. Front. Genet. 2019, 10, 950. [CrossRef] [PubMed]

2. Marchio, P.; Guerra-Ojeda, S.; Vila, J.M.; Aldasoro, M.; Victor, V.M.; Mauricio, M.D. Targeting Early Atherosclerosis: A Focus on Oxidative Stress and Inflammation. Oxid. Med. Cell Longev. 2019, 2019, 8563845. [CrossRef]

3. Libby, P.; Buring, J.E.; Badimon, L.; Hansson, G.K.; Deanfield, J.; Bittencourt, M.S.; Tokgozoglu, L.; Lewis, E.F. Atherosclerosis. Nat. Rev. Dis. Primers 2019, 5, 56. [CrossRef] [PubMed]

4. Maamoun, H.; Abdelsalam, S.S.; Zeidan, A.; Korashy, H.M.; Agouni, A. Endoplasmic Reticulum Stress: A Critical Molecular Driver of Endothelial Dysfunction and Cardiovascular Disturbances Associated with Diabetes. Int. J. Mol. Sci. 2019, 20, 1658. [CrossRef] [PubMed]

5. Vion, A.C.; Ramkhelawon, B.; Loyer, X.; Chironi, G.; Devue, C.; Loirand, G.; Tedgui, A.; Lehoux, S.; Boulanger, C.M. Shear stress regulates endothelial microparticle release. Circ. Res. 2013, 112, 1323-1333. [CrossRef] [PubMed]

6. Yin, J.; Hou, X.; Yang, S. microRNA-338-3p promotes ox-LDL-induced endothelial cell injury through targeting BAMBI and activating TGF- $\beta /$ Smad pathway. J. Cell. Physiol. 2019, 234, 11577-11586. [CrossRef] [PubMed]

7. Doke, S.K.; Dhawale, S.C. Alternatives to animal testing: A review. Saudi Pharm J. 2015, 23, $223-229$. [CrossRef]

8. Barre-Sinoussi, F.; Montagutelli, X. Animal models are essential to biological research: Issues and perspectives. Future Sci. OA 2015, 1, FSO63. [CrossRef]

9. MacGowan, A.; Rogers, C.; Bowker, K. In vitro models, in vivo models, and pharmacokinetics: What can we learn from in vitro models? Clin. Infect. Dis. 2001, 33, S214-S220. [CrossRef]

10. Roudsari, L.C.; West, J.L. Studying the influence of angiogenesis in in vitro cancer model systems. Adv. Drug Deliv. Rev. 2016, 97, 250-259. [CrossRef]

11. Baudin, B.; Bruneel, A.; Bosselut, N.; Vaubourdolle, M. A protocol for isolation and culture of human umbilical vein endothelial cells. Nat. Protoc. 2007, 2, 481-485. [CrossRef] [PubMed]

12. Rhim, J.S.; Tsai, W.P.; Chen, Z.Q.; Chen, Z.; Van Waes, C.; Burger, A.M.; Lautenberger, J.A. A human vascular endothelial cell model to study angiogenesis and tumorigenesis. Carcinogenesis 1998, 19, 673-681. [CrossRef] [PubMed]

13. Onat, D.; Brillon, D.; Colombo, P.C.; Schmidt, A.M. Human vascular endothelial cells: A model system for studying vascular inflammation in diabetes and atherosclerosis. Curr. Diab. Rep. 2011, 11, 193-202. [CrossRef] [PubMed]

14. Schleger, C.; Platz, S.J.; Deschl, U. Development of an in vitro model for vascular injury with human endothelial cells. ALTEX 2004, 21 (Suppl 3), 12-19.

15. Fearon, I.M.; Gaca, M.D.; Nordskog, B.K. In vitro models for assessing the potential cardiovascular disease risk associated with cigarette smoking. Toxicol. In Vitro 2013, 27, 513-522. [CrossRef]

16. Carlson, B.M. Establishment of the Basic Embryonic Body Plan. In Human Embryology and Developmental Biology, 5th ed.; Carlson, B.M., Ed.; Elsevier: Philadelphia, PA, USA, 2014; pp. 111-115.

17. Can, A.; Karahuseyinoglu, S. Concise review: Human umbilical cord stroma with regard to the source of fetus-derived stem cells. Stem Cells 2007, 25, 2886-2895. [CrossRef]

18. Kim, D.W.; Staples, M.; Shinozuka, K.; Pantcheva, P.; Kang, S.D.; Borlongan, C.V. Wharton's Jelly-Derived Mesenchymal Stem Cells: Phenotypic Characterization and Optimizing Their Therapeutic Potential for Clinical Applications. Int. J. Mol. Sci 2013, 14, 11692-11712. [CrossRef] 
19. Kobayashi, K.; Kubota, T.; Aso, T. Study on myofibroblast differentiation in the stromal cells of Wharton's jelly: Expression and localization of alpha-smooth muscle actin. Early Hum. Dev. 1998, 51, 223-233. [CrossRef]

20. Weiss, M.L.; Medicetty, S.; Bledsoe, A.R.; Rachakatla, R.S.; Choi, M.; Merchav, S.; Luo, Y.; Rao, M.S.; Velagaleti, G.; Troyer, D. Human umbilical cord matrix stem cells: Preliminary characterization and effect of transplantation in a rodent model of Parkinson's disease. Stem Cells 2006, 24, 781-792. [CrossRef]

21. Wang, H.S.; Hung, S.C.; Peng, S.T.; Huang, C.C.; Wei, H.M.; Guo, Y.J.; Fu, Y.S.; Lai, M.C.; Chen, C.C. Mesenchymal stem cells in the Wharton's jelly of the human umbilical cord. Stem Cells 2004, 22, 1330-1337. [CrossRef]

22. Mizoguchi, M.; Suga, Y.; Sanmano, B.; Ikeda, S.; Ogawa, H. Organotypic culture and surface plantation using umbilical cord epithelial cells: Morphogenesis and expression of differentiation markers mimicking cutaneous epidermis. J. Dermatol. Sci. 2004, 35, 199-206. [CrossRef] [PubMed]

23. Miki, T.; Lehmann, T.; Cai, H.; Stolz, D.B.; Strom, S.C. Stem cell characteristics of amniotic epithelial cells. Stem Cells 2005, 23, 1549-1559. [CrossRef] [PubMed]

24. Garzon, I.; Alfonso-Rodriguez, C.A.; Martinez-Gomez, C.; Carriel, V.; Martin-Piedra, M.A.; Fernandez-Valades, R.; Sanchez-Quevedo, M.C.; Alaminos, M. Expression of epithelial markers by human umbilical cord stem cells. A topographical analysis. Placenta 2014, 35, 994-1000. [CrossRef] [PubMed]

25. Taghizadeh, R.R.; Cetrulo, K.J.; Cetrulo, C.L. Wharton's Jelly stem cells: Future clinical applications. Placenta 2011, 32 (Suppl 4), S311-S315. [CrossRef]

26. Schultheiss, D.; Bloom, D.A.; Wefer, J.; Jonas, U. Tissue engineering from Adam to the zygote: Historical reflections. World J. Urol. 2000, 18, 84-90. [CrossRef] [PubMed]

27. Lewis, W.H. Endothelium in tissue cultures. Am. J. Anat. 1922, 30, 39-59. [CrossRef]

28. Jaffe, E. Culture of human endothelial cells derived from umbilical veins. J. Clin. Invest. 1973, 52, $2745-2756$. [CrossRef]

29. Gimbrone, M.A., Jr.; Cotran, R.S.; Folkman, J. Human vascular endothelial cells in culture. Growth and DNA synthesis. J. Cell Biol. 1974, 60, 673-684. [CrossRef]

30. Quesenberry, P.J.; Gimbrone, M.J. Vascular endothelium as a regulator of granulopoiesis: Production of colony-stimulating activity by cultured human endothelial cells. Blood 1980, 56, 1060-1067. [CrossRef]

31. Killackey, J.J.; Johnston, M.G.; Movat, H.Z. Increased permeability of microcarrier-cultured endothelial monolayers in response to histamine and thrombin. A model for the in vitro study of increased vasopermeability. Am. J. Pathol 1986, 122, 50-61.

32. Vaccaro, P.S.; Joseph, L.B.; Titterington, L.; Stephens, R.E. Methods for the initiation and maintenance of human endothelial cell culture. Vasc. Surg. 1987, 21, 391-400. [CrossRef]

33. Zwaginga, J.; Sixma, J.; de Groot, P.G. Activation of endothelial cells induces platelet thrombus formation on their matrix. Studies of new in vitro thrombosis model with low molecular weight heparin as anticoagulant. Arterioscler. An. Off. J. Am. Heart Assoc. Inc. 1990, 10, 49-61. [CrossRef]

34. Koenig, A.; Yakisan, E.; Reuter, M.; Huang, M.; Sykora, K.W.; Corbacioglu, S.; Welte, K. Differential regulation of stem cell factor mRNA expression in human endothelial cells by bacterial pathogens: An in vitro model of inflammation. Blood 1994, 83, 2836-2843. [CrossRef]

35. Waldman, W.J.; Knight, D.A.; Huang, E.H. An in vitro model of $\mathrm{T}$ cell activation by autologous cytomegalovirus (CMV)-infected human adult endothelial cells: Contribution of CMV-enhanced endothelial ICAM-1. J. Immunol. 1998, 160, 3143-3151. [PubMed]

36. Lee, O.H.; Bae, S.K.; Bae, M.H.; Lee, Y.M.; Moon, E.J.; Cha, H.J.; Kwon, Y.G.; Kim, K.W. Identification of angiogenic properties of insulin-like growth factor II in in vitro angiogenesis models. Br. J. Cancer 2000, 82, 385-391. [CrossRef] [PubMed]

37. Vailhe, B.; Vittet, D.; Feige, J.J. In vitro models of vasculogenesis and angiogenesis. Lab. Invest. 2001, 81, 439-452. [CrossRef]

38. Starke, R.D.; Ferraro, F.; Paschalaki, K.E.; Dryden, N.H.; McKinnon, T.A.; Sutton, R.E.; Payne, E.M.; Haskard, D.O.; Hughes, A.D.; Cutler, D.F.; et al. Endothelial von Willebrand factor regulates angiogenesis. Blood 2011, 117, 1071-1080. [CrossRef]

39. Park, J.Y.; Kim, B.S.; Lee, J. Evaluation of the angiogenic potency of a novel exopolysaccharide produced by the MK1 bacterial strain. Arch. Pharm. Res. 2016, 39, 1223-1231. [CrossRef]

40. Maruyama, Y. The human endothelial cell in tissue culture. Z Zellforsch Mikrosk Anat 1963, 60, 69-79. [CrossRef] 
41. Henriksen, T.; Evensen, S.A.; Elgjo, R.F.; Vefling, A. Human fetal endothelial cells in culture. Scand. J. Haematol. 1975, 14, 233-241. [CrossRef]

42. Marin, V.; Kaplanski, G.; Gres, S.; Farnarier, C.; Bongrand, P. Endothelial cell culture: Protocol to obtain and cultivate human umbilical endothelial cells. J. Immunol. Methods 2001, 254, 183-190. [CrossRef]

43. Cheung, A.L. Isolation and culture of human umbilical vein endothelial cells (HUVEC). Curr. Protoc. Microbiol 2007, 4, A.4B.1-A.4B.8. [CrossRef]

44. Lopez-Macay, A.; Ruiz-Medina, E.J.; Ventura-Gallegos, J.L.; Arechavaleta-Velasco, F.; Gomez-Quiroz, L.E.; Konigsberg-Fainstein, M.; Zentella-Dehesa, A. Characterization of hemodynamic ex vivo model to study endothelial activation by TNF-alpha in prefunded human veins. Gac Med. Mex 2015, 151, 206-215. [PubMed]

45. Weibel, E.R.; Palade, G.E. New Cytoplasmic Components in Arterial Endothelia. J. Cell Biol. 1964, 23, 101-112. [CrossRef] [PubMed]

46. Yamamoto, K. Human endothelial cells in culture. Arch. Histol. Jpn. 1979, 42, 1-10. [CrossRef] [PubMed]

47. Haudenschild, C.C.; Cotran, R.S.; Gimbrone, M.A., Jr.; Folkman, J. Fine structure of vascular endothelium in culture. J. Ultrastruct. Res. 1975, 50, 22-32. [CrossRef]

48. Elgjo, R.F.; Henriksen, T.; Evensen, S.A. Ultrastructural identification of umbilical cord vein endothelium in situ and in culture. Cell Tissue Res. 1975, 162, 49-59. [CrossRef] [PubMed]

49. Bachetti, T.; Morbidelli, L. Endothelial cells in culture: A model for studying vascular functions. Pharmacol. Res. 2000, 42, 9-19. [CrossRef]

50. Larrivée, B.; Karsan, A. Isolation and culture of primary endothelial cells. In Basic Cell Culture Protocols; Helgason, C.D., Miller, C.L., Eds.; Springer: Basel, Switzerland, 2005; pp. 315-329.

51. Shao, C.; Chen, J.; Chen, P.; Zhu, M.; Yao, Q.; Gu, P.; Fu, Y.; Fan, X. Targeted transplantation of human umbilical cord blood endothelial progenitor cells with immunomagnetic nanoparticles to repair corneal endothelium defect. Stem Cells Dev. 2015, 24, 756-767. [CrossRef]

52. Yin, Y.; Liu, H.; Wang, F.; Li, L.; Deng, M.; Huang, L.; Zhao, X. Transplantation of cryopreserved human umbilical cord blood-derived endothelial progenitor cells induces recovery of carotid artery injury in nude rats. Stem Cell Res. Ther. 2015, 6, 37. [CrossRef]

53. Huang, M.; Qiu, Q.; Zeng, S.; Xiao, Y.; Shi, M.; Zou, Y.; Ye, Y.; Liang, L.; Yang, X.; Xu, H. Niclosamide inhibits the inflammatory and angiogenic activation of human umbilical vein endothelial cells. Inflamm. Res. 2015, 64, 1023-1032. [CrossRef] [PubMed]

54. Borges, L.E.; Bloise, E.; Dela Cruz, C.; Galleri, L.; Apa, R.; Petraglia, F.; Reis, F.M. Urocortin 1 expression and secretion by human umbilical vein endothelial cells: In vitro effects of interleukin 8 , interferon gamma, lipopolysaccharide, endothelin 1, prostaglandin F-2alpha, estradiol, progesterone and dexamethasone. Peptides 2015, 74, 64-69. [CrossRef] [PubMed]

55. Rapp, B.M.; Saadatzedeh, M.R.; Ofstein, R.H.; Bhavsar, J.R.; Tempel, Z.S.; Moreno, O.; Morone, P.; Booth, D.A.; Traktuev, D.O.; Dalsing, M.C. Resident endothelial progenitor cells from human placenta have greater vasculogenic potential than circulating endothelial progenitor cells from umbilical cord blood. Cell Med. 2011, 2, 85-96. [CrossRef]

56. Shen, C.; Lie, P.; Miao, T.; Yu, M.; Lu, Q.; Feng, T.; Li, J.; Zu, T.; Liu, X.; Li, H. Conditioned medium from umbilical cord mesenchymal stem cells induces migration and angiogenesis. Mol. Med. Rep. 2015, 12, $20-30$. [CrossRef] [PubMed]

57. Ebrahim, N.A.; Leach, L. Temporal studies into attachment, VE-cadherin perturbation, and paracellular migration of human umbilical mesenchymal stem cells across umbilical vein endothelial monolayers. Stem Cells Dev. 2014, 24, 426-436. [CrossRef] [PubMed]

58. Cheng, X.; Chapple, S.J.; Patel, B.; Puszyk, W.; Sugden, D.; Yin, X.; Mayr, M.; Siow, R.C.; Mann, G.E. Gestational diabetes mellitus impairs Nrf2-mediated adaptive antioxidant defenses and redox signaling in fetal endothelial cells in utero. Diabetes 2013, 62, 4088-4097. [CrossRef]

59. Namiki, A.; Brogi, E.; Kearney, M.; Kim, E.A.; Wu, T.; Couffinhal, T.; Varticovski, L.; Isner, J.M. Hypoxia induces vascular endothelial growth factor in cultured human endothelial cells. J. Biol. Chem. 1995, 270, 31189-31195. [CrossRef]

60. Wisgrill, L.; Muck, M.; Wessely, I.; Berger, A.; Spittler, A.; Forster-Waldl, E.; Sadeghi, K. Endothelial cells of extremely premature infants display impaired immune response after proinflammatory stimulation. Pediatr. Res. 2018, 83, 128-134. [CrossRef] 
61. Nussbaum, C.; Gloning, A.; Pruenster, M.; Frommhold, D.; Bierschenk, S.; Genzel-Boroviczeny, O.; von Andrian, U.H.; Quackenbush, E.; Sperandio, M. Neutrophil and endothelial adhesive function during human fetal ontogeny. J. Leukoc. Biol. 2013, 93, 175-184. [CrossRef]

62. Illsinger, S.; Janzen, N.; Sander, S.; Bode, J.; Mallunat, L.; Thomasmeyer, R.; Hagebolling, F.; Schmidt, K.H.; Bednarczyk, J.; Vaske, B.; et al. Energy metabolism in umbilical endothelial cells from preterm and term neonates. J. Perinat. Med. 2011, 39, 587-593. [CrossRef]

63. Lorant, D.E.; Li, W.; Tabatabaei, N.; Garver, M.K.; Albertine, K.H. P-selectin expression by endothelial cells is decreased in neonatal rats and human premature infants. Blood 1999, 94, 600-609. [CrossRef] [PubMed]

64. Kandasamy, J.; Olave, N.; Ballinger, S.W.; Ambalavanan, N. Vascular Endothelial Mitochondrial Function Predicts Death or Pulmonary Outcomes in Preterm Infants. Am. J. Respir. Crit. Care Med. 2017, 196, 1040-1049. [CrossRef] [PubMed]

65. Jimenez, N.; Krouwer, V.J.; Post, J.A. A new, rapid and reproducible method to obtain high quality endothelium in vitro. Cytotechnology 2013, 65, 1-14. [CrossRef] [PubMed]

66. Peirce, E.C. Tissue-culture evaluation of the viability of blood vessels stored by refrigeration. Ann. Surg. 1949, 129, 333. [CrossRef] [PubMed]

67. Manconi, F.; Markham, R.; Fraser, I.S. Culturing endothelial cells of microvascular origin. Methods Cell Sci. 2000, 22, 89-99. [CrossRef]

68. Thornton, S.C.; Mueller, S.N.; Levine, E.M. Human endothelial cells: Use of heparin in cloning and long-term serial cultivation. Science 1983, 222, 623-625. [CrossRef]

69. Ulrich-Merzenich, G.; Metzner, C.; Bhonde, R.R.; Malsch, G.; Schiermeyer, B.; Vetter, H. Simultaneous isolation of endothelial and smooth muscle cells from human umbilical artery or vein and their growth response to low-density lipoproteins. In Vitro Cell. Dev. Biol. Anim. 2002, 38, 265-272. [CrossRef]

70. Freshney, R.I. Culture of specific cell types. In Culture of Animal Cells: A Manual of Basic Technique; Freshney, R.I., Ed.; Wiley-Blackwell: Hoboken, NJ, USA, 2005.

71. Jarrell, B.; Levine, E.; Shapiro, S.; Williams, S.; Carabasi, R.A.; Mueller, S.; Thornton, S. Human adult endothelial cell growth in culture. J. Vasc. Surg. 1984, 1, 757-764. [CrossRef]

72. Maciag, T.; Hoover, G.A.; Stemerman, M.B.; Weinstein, R. Serial propagation of human endothelial cells in vitro. J. Cell Biol. 1981, 91, 420-426. [CrossRef]

73. Garbern, J.C.; Mummery, C.L.; Lee, R.T. Model systems for cardiovascular regenerative biology. Cold Spring Harb Perspect Med. 2013, 3, a014019. [CrossRef]

74. Monti, M.; Terzuoli, E.; Ziche, M.; Morbidelli, L. H2S dependent and independent anti-inflammatory activity of zofenoprilat in cells of the vascular wall. Pharmacol. Res. 2016, 113, 426-437. [CrossRef] [PubMed]

75. Bouis, D.; Hospers, G.A.; Meijer, C.; Molema, G.; Mulder, N.H. Endothelium in vitro: A review of human vascular endothelial cell lines for blood vessel-related research. Angiogenesis 2001, 4, 91-102. [CrossRef] [PubMed]

76. Addis, R.; Campesi, I.; Fois, M.; Capobianco, G.; Dessole, S.; Fenu, G.; Montella, A.; Cattaneo, M.G.; Vicentini, L.M.; Franconi, F. Human umbilical endothelial cells (HUVECs) have a sex: Characterisation of the phenotype of male and female cells. Biol. Sex. Differ. 2014, 5, 18. [CrossRef] [PubMed]

77. Lorenz, M.; Blaschke, B.; Benn, A.; Hammer, E.; Witt, E.; Kirwan, J.; Fritsche-Guenther, R.; Gloaguen, Y.; Bartsch, C.; Vietzke, A.; et al. Sex-specific metabolic and functional differences in human umbilical vein endothelial cells from twin pairs. Atherosclerosis 2019, 291, 99-106. [CrossRef] [PubMed]

78. Lorenz, M.; Koschate, J.; Kaufmann, K.; Kreye, C.; Mertens, M.; Kuebler, W.M.; Baumann, G.; Gossing, G.; Marki, A.; Zakrzewicz, A.; et al. Does cellular sex matter? Dimorphic transcriptional differences between female and male endothelial cells. Atherosclerosis 2015, 240, 61-72. [CrossRef] [PubMed]

79. Zhang, Y.; Lingappan, K. Differential sex-specific effects of oxygen toxicity in human umbilical vein endothelial cells. Biochem. Biophys. Res. Commun. 2017, 486, 431-437. [CrossRef] [PubMed]

80. Staton, C.A.; Reed, M.W.; Brown, N.J. A critical analysis of current in vitro and in vivo angiogenesis assays. Int. J. Exp. Pathol. 2009, 90, 195-221. [CrossRef]

81. Haudenschild, C.C.; Zahniser, D.; Folkman, J.; Klagsbrun, M. Human vascular endothelial cells in culture. Lack of response to serum growth factors. Exp. Cell Res. 1976, 98, 175-183. [CrossRef]

82. Folkman, J.; Haudenschild, C.C.; Zetter, B.R. Long-term culture of capillary endothelial cells. Proc. Natl. Acad. Sci. USA 1979, 76, 5217-5221. [CrossRef] 
83. Franke, R.P.; Grafe, M.; Schnittler, H.; Seiffge, D.; Mittermayer, C.; Drenckhahn, D. Induction of human vascular endothelial stress fibres by fluid shear stress. Nature 1984, 307, 648-649. [CrossRef]

84. Pu, F.R.; Williams, R.L.; Markkula, T.K.; Hunt, J.A. Expression of leukocyte-endothelial cell adhesion molecules on monocyte adhesion to human endothelial cells on plasma treated PET and PTFE in vitro. Biomaterials 2002, 23, 4705-4718. [CrossRef]

85. Ho, M.; Yang, E.; Matcuk, G.; Deng, D.; Sampas, N.; Tsalenko, A.; Tabibiazar, R.; Zhang, Y.; Chen, M.; Talbi, S.; et al. Identification of endothelial cell genes by combined database mining and microarray analysis. Physiol. Genomics 2003, 13, 249-262. [CrossRef] [PubMed]

86. Floris, I.; Descamps, B.; Vardeu, A.; Mitic, T.; Posadino, A.M.; Shantikumar, S.; Sala-Newby, G.; Capobianco, G.; Mangialardi, G.; Howard, L.; et al. Gestational Diabetes Mellitus Impairs Fetal Endothelial Cell Functions Through a Mechanism Involving MicroRNA-101 and Histone Methyltransferase Enhancer of Zester Homolog-2. Arterioscl. Throm. Vas. 2015, 35, 664-674. [CrossRef] [PubMed]

87. Albelda, S.M.; Muller, W.A.; Buck, C.A.; Newman, P.J. Molecular and cellular properties of PECAM-1 (endoCAM/CD31): A novel vascular cell-cell adhesion molecule. J. Cell Biol. 1991, 114, 1059-1068. [CrossRef]

88. Dawson, D.W.; Pearce, S.F.; Zhong, R.; Silverstein, R.L.; Frazier, W.A.; Bouck, N.P. CD36 mediates the In vitro inhibitory effects of thrombospondin-1 on endothelial cells. J. Cell Biol. 1997, 138, 707-717. [CrossRef]

89. Greenwalt, D.E.; Lipsky, R.H.; Ockenhouse, C.F.; Ikeda, H.; Tandon, N.N.; Jamieson, G.A. Membrane glycoprotein CD36: A review of its roles in adherence, signal transduction, and transfusion medicine. Blood 1992, 80, 1105-1115. [CrossRef]

90. Nickoloff, B.J. The human progenitor cell antigen (CD34) is localized on endothelial cells, dermal dendritic cells, and perifollicular cells in formalin-fixed normal skin, and on proliferating endothelial cells and stromal spindle-shaped cells in Kaposi's sarcoma. Arch. Dermatol. 1991, 127, 523-529. [CrossRef]

91. Pusztaszeri, M.P.; Seelentag, W.; Bosman, F.T. Immunohistochemical expression of endothelial markers CD31, CD34, von Willebrand factor, and Fli-1 in normal human tissues. J. Histochem. Cytochem. 2006, 54, 385-395. [CrossRef]

92. Keiper, T.; Santoso, S.; Nawroth, P.; Orlova, V.; Chavakis, T. The role of junctional adhesion molecules in cell-cell interactions. Histol. Histopathol. 2005, 20, 197-203.

93. Doan, C.C.; Le, T.L.; Hoang, N.S.; Doan, N.T.; Le, V.D.; Do, M.S. Differentiation of umbilical cord lining membrane-derived mesenchymal stem cells into endothelial-like cells. Iran. Biomed. J. 2014, 18, 67.

94. Steffen, B.J.; Butcher, E.C.; Engelhardt, B. Evidence for involvement of ICAM-1 and VCAM-1 in lymphocyte interaction with endothelium in experimental autoimmune encephalomyelitis in the central nervous system in the SJL/J mouse. Am. J. Pathol 1994, 145, 189-201. [PubMed]

95. Davies, M.J.; Gordon, J.L.; Gearing, A.J.; Pigott, R.; Woolf, N.; Katz, D.; Kyriakopoulos, A. The expression of the adhesion molecules ICAM-1, VCAM-1, PECAM, and E-selectin in human atherosclerosis. J. Pathol. 1993, 171, 223-229. [CrossRef] [PubMed]

96. Wagner, O.F.; Christ, G.; Wojta, J.; Vierhapper, H.; Parzer, S.; Nowotny, P.J.; Schneider, B.; Waldhausl, W.; Binder, B.R. Polar secretion of endothelin-1 by cultured endothelial cells. J. Biol. Chem. 1992, 267, 16066-16068. [PubMed]

97. Dong, Z.M.; Chapman, S.M.; Brown, A.A.; Frenette, P.S.; Hynes, R.O.; Wagner, D.D. The combined role of Pand E-selectins in atherosclerosis. J. Clin. Invest. 1998, 102, 145-152. [CrossRef]

98. Asa, D.; Raycroft, L.; Ma, L.; Aeed, P.A.; Kaytes, P.S.; Elhammer, A.P.; Geng, J.-G. The P-selectin glycoprotein ligand functions as a common human leukocyte ligand for P-and E-selectins. J. Biol. Chem. 1995, 270, 11662-11670. [CrossRef]

99. Rice, J.W.; Davis, J.E.; Crowl, R.M.; Johnston, P.A. Development of a high volume screen to identify inhibitors of endothelial cell activation. Anal. Biochem 1996, 241, 254-259. [CrossRef]

100. Kluger, M.S.; Clark, P.R.; Tellides, G.; Gerke, V.; Pober, J.S. Claudin-5 controls intercellular barriers of human dermal microvascular but not human umbilical vein endothelial cells. Arterioscler. Thromb. Vasc. Biol. 2013, 33, 489-500. [CrossRef]

101. Morita, K.; Sasaki, H.; Furuse, M.; Tsukita, S. Endothelial claudin: Claudin-5/TMVCF constitutes tight junction strands in endothelial cells. J. Cell Biol. 1999, 147, 185-194. [CrossRef]

102. Voyta, J.C.; Via, D.P.; Butterfield, C.E.; Zetter, B.R. Identification and isolation of endothelial cells based on their increased uptake of acetylated-low density lipoprotein. J. Cell Biol. 1984, 99, 2034-2040. [CrossRef] 
103. Pober, J.S.; Sessa, W.C. Evolving functions of endothelial cells in inflammation. Nat. Rev. Immunol. 2007, 7, 803-815. [CrossRef]

104. Birukova, A.A.; Zagranichnaya, T.; Fu, P.; Alekseeva, E.; Chen, W.; Jacobson, J.R.; Birukov, K.G. Prostaglandins PGE2 and PGI2 promote endothelial barrier enhancement via PKA-and Epac1/Rap1-dependent Rac activation. Exp. Cell Res. 2007, 313, 2504-2520. [CrossRef] [PubMed]

105. Yang, S.; Graham, J.; Kahn, J.W.; Schwartz, E.A.; Gerritsen, M.E. Functional roles for PECAM-1 (CD31) and VE-cadherin (CD144) in tube assembly and lumen formation in three-dimensional collagen gels. Am. J. Pathol. 1999, 155, 887-895. [CrossRef]

106. Tian, Y.; Jain, S.; Kelemen, S.E.; Autieri, M.V. AIF-1 expression regulates endothelial cell activation, signal transduction, and vasculogenesis. Am. J. Physiol. Cell Physiol. 2009, 296, C256-C266. [CrossRef] [PubMed]

107. Takase, H.; Matsumoto, K.; Yamadera, R.; Kubota, Y.; Otsu, A.; Suzuki, R.; Ishitobi, H.; Mochizuki, H.; Kojima, T.; Takano, S.; et al. Genome-wide identification of endothelial cell-enriched genes in the mouse embryo. Blood 2012, 120, 914-923. [CrossRef]

108. Wu, F.; Song, H.; Zhang, Y.; Zhang, Y.; Mu, Q.; Jiang, M.; Wang, F.; Zhang, W.; Li, L.; Li, H.; et al. Irisin Induces Angiogenesis in Human Umbilical Vein Endothelial Cells In Vitro and in Zebrafish Embryos In Vivo via Activation of the ERK Signaling Pathway. PLoS ONE 2015, 10, e0134662. [CrossRef]

109. Fiordelisi, A.; Iaccarino, G.; Morisco, C.; Coscioni, E.; Sorriento, D. NFkappaB is a Key Player in the Crosstalk between Inflammation and Cardiovascular Diseases. Int. J. Mol. Sci. 2019, 20, 1599. [CrossRef]

110. Hoare, D.; Bussooa, A.; Neale, S.; Mirzai, N.; Mercer, J. The Future of Cardiovascular Stents: Bioresorbable and Integrated Biosensor Technology. Adv. Sci. (Weinh) 2019, 6, 1900856. [CrossRef]

111. Kruger-Genge, A.; Blocki, A.; Franke, R.P.; Jung, F. Vascular Endothelial Cell Biology: An Update. Int. J. Mol. Sci. 2019, 20, 4411. [CrossRef]

112. Liu, S.G.; Yi, F.F.; Cheng, W.W.; Qu, X.; Wang, C.T. Molecular mechanisms in vascular injury induced by hypertension: Expression and role of microRNA-34a. Exp. Ther. Med. 2017, 14, 5497-5502. [CrossRef]

113. Zhao, Z.; Sun, W.; Guo, Z.; Zhang, J.; Yu, H.; Liu, B. Mechanisms of lncRNA/microRNA interactions in angiogenesis. Life Sci. 2019, 116900. [CrossRef]

114. Churov, A.; Summerhill, V.; Grechko, A.; Orekhova, V.; Orekhov, A. MicroRNAs as Potential Biomarkers in Atherosclerosis. Int J. Mol. Sci. 2019, 20, 5547. [CrossRef] [PubMed]

115. Kriegel, A.J.; Baker, M.A.; Liu, Y.; Liu, P.; Cowley, A.W., Jr.; Liang, M. Endogenous microRNAs in human microvascular endothelial cells regulate mRNAs encoded by hypertension-related genes. Hypertension 2015, 66, 793-799. [CrossRef] [PubMed]

116. Buzinari, T.C.; Oishi, J.C.; De Moraes, T.F.; Vatanabe, I.P.; Selistre-de-Araujo, H.S.; Pestana, C.R.; Rodrigues, G.J. Treatment with sodium nitroprusside improves the endothelial function in aortic rings with endothelial dysfunction. Eur. J. Pharm. Sci. 2017, 105, 144-149. [CrossRef] [PubMed]

117. Wang, C.; He, Y.; Yang, M.; Sun, H.; Zhang, S.; Wang, C. Safflor yellow B suppresses angiotensin II-mediated human umbilical vein cell injury via regulation of Bcl-2/p22phox expression. Toxicol. Appl. Pharmacol. 2013, 273, 59-67. [CrossRef] [PubMed]

118. Fernandez-Cruz, E.; Cerezo, A.B.; Cantos-Villar, E.; Richard, T.; Troncoso, A.M.; Garcia-Parrilla, M.C. Inhibition of VEGFR-2 Phosphorylation and Effects on Downstream Signaling Pathways in Cultivated Human Endothelial Cells by Stilbenes from Vitis Spp. J. Agric. Food Chem. 2019, 67, 3909-3918. [CrossRef] [PubMed]

119. Herrero-Fernandez, B.; Gomez-Bris, R.; Somovilla-Crespo, B.; Gonzalez-Granado, J.M. Immunobiology of Atherosclerosis: A Complex Net of Interactions. Int. J. Mol. Sci. 2019, 20, 5293. [CrossRef] [PubMed]

120. Lee, D.Y.; Chiu, J.J. Atherosclerosis and flow: Roles of epigenetic modulation in vascular endothelium. J. Biomed. Sci 2019, 26, 56. [CrossRef]

121. Ge, C.; Song, J.; Chen, L.; Wang, L.; Chen, Y.; Liu, X.; Zhang, Y.; Zhang, L.; Zhang, M. Atheroprotective pulsatile flow induces ubiquitin-proteasome-mediated degradation of programmed cell death 4 in endothelial cells. PLoS ONE 2014, 9, e91564. [CrossRef]

122. Souilhol, C.; Gauci, I.; Feng, S.; Tardajos Ayllon, B.; Mahmoud, M.; Canham, L.; Fragiadaki, M.; Serbanovic-Canic, J.; Ridger, V.; Evans, P.C. Homeobox B9 integrates bone morphogenic protein 4 with inflammation at atheroprone sites. Cardiovasc. Res. 2019, cvz235. [CrossRef] 
123. Krause, M.D.; Huang, R.T.; Wu, D.; Shentu, T.P.; Harrison, D.L.; Whalen, M.B.; Stolze, L.K.; Di Rienzo, A.; Moskowitz, I.P.; Civelek, M.; et al. Genetic variant at coronary artery disease and ischemic stroke locus 1 p32.2 regulates endothelial responses to hemodynamics. Proc. Natl. Acad. Sci. USA 2018, 115, E11349-E11358. [CrossRef]

124. Sheikh, S.; Gale, Z.; Rainger, G.E.; Nash, G.B. Methods for exposing multiple cultures of endothelial cells to different fluid shear stresses and to cytokines, for subsequent analysis of inflammatory function. J. Immunol. Methods 2004, 288, 35-46. [CrossRef] [PubMed]

125. Cai, Z.H.; Zhang, Y.Y.; Zhang, Y.R.A.; Miao, X.F.; Li, S.; Yang, H.; Ling, Q.J.; Hoffinann, P.R.; Huang, Z. Use of a Mouse Model and Human Umbilical Vein Endothelial Cells to Investigate the Effect of Arsenic Exposure on Vascular Endothelial Function and the Associated Role of Calpains. Environ. Health Persp. 2019, 127, 077003. [CrossRef] [PubMed]

126. Yang, L.; Liu, J.; Qi, G. Mechanism of the effect of saikosaponin on atherosclerosis in vitro is based on the MAPK signaling pathway. Mol. Med. Rep. 2017, 16, 8868-8874. [CrossRef] [PubMed]

127. Gliozzi, M.; Scicchitano, M.; Bosco, F.; Musolino, V.; Carresi, C.; Scarano, F.; Maiuolo, J.; Nucera, S.; Maretta, A.; Paone, S.; et al. Modulation of Nitric Oxide Synthases by Oxidized LDLs: Role in Vascular Inflammation and Atherosclerosis Development. Int. J. Mol. Sci 2019, 20, 3294. [CrossRef]

128. Da, J.J.; Zhuo, M.; Qian, M.Z. MCPIP is induced by cholesterol and participated in cholesterol-caused DNA damage in HUVEC. Int. J. Clin. Exp. Patho 2015, 8, 10625-10634.

129. Zhou, B.; Ren, C.; Zu, L.; Zheng, L.; Guo, L.; Gao, W. Elevated plasma migration inhibitory factor in hypertension-hyperlipidemia patients correlates with impaired endothelial function. Medicine (Baltimore) 2016, 95, e5207. [CrossRef]

130. Araujo, P.; Belghit, I.; Aarsaether, N.; Espe, M.; Lucena, E.; Holen, E. The Effect of Omega-3 and Omega-6 Polyunsaturated Fatty Acids on the Production of Cyclooxygenase and Lipoxygenase Metabolites by Human Umbilical Vein Endothelial Cells. Nutrients 2019, 11, 966. [CrossRef]

131. Abudawood, M. Diabetes and cancer: A comprehensive review. J. Res. Med. Sci. 2019, 24, 94. [CrossRef]

132. Dal Canto, E.; Ceriello, A.; Rydén, L.; Ferrini, M.; Hansen, T.B.; Schnell, O.; Standl, E.; Beulens, J.W. Diabetes as a cardiovascular risk factor: An overview of global trends of macro and micro vascular complications. Eur. J. Prev. Cardiol. 2019, 26 (Suppl 2), 25-32. [CrossRef]

133. Katsiki, N.; Banach, M.; Mikhailidis, D.P. Is type 2 diabetes mellitus a coronary heart disease equivalent or not? Do not just enjoy the debate and forget the patient! Arch. Med. Sci. 2019, 15, 1357-1364. [CrossRef]

134. Ryden, L.; Ferrannini, G.; Mellbin, L. Risk factor reduction in type 2 diabetes demands a multifactorial approach. Eur. J. Prev. Cardiol. 2019, 26, 81-91. [CrossRef] [PubMed]

135. Pujadas, G.; De Nigris, V.; Prattichizzo, F.; La Sala, L.; Testa, R.; Ceriello, A. The dipeptidyl peptidase-4 (DPP-4) inhibitor teneligliptin functions as antioxidant on human endothelial cells exposed to chronic hyperglycemia and metabolic high-glucose memory. Endocrine 2017, 56, 509-520. [CrossRef] [PubMed]

136. Chen, X.; Duong, M.N.; Psaltis, P.J.; Bursill, C.A.; Nicholls, S.J. High-density lipoproteins attenuate high glucose-impaired endothelial cell signaling and functions: Potential implications for improved vascular repair in diabetes. Cardiovasc. Diabetol. 2017, 16, 121. [CrossRef] [PubMed]

137. Wang, H.; Wang, Z.X.; Tang, Q.B. Reduced expression of microRNA-199a-3p is associated with vascular endothelial cell injury induced by type 2 diabetes mellitus. Exp. Ther. Med. 2018, 16, 3639-3645. [CrossRef]

138. Yan, H.Y.; Bu, S.Z.; Zhou, W.B.; Mai, Y.F. TUG1 promotes diabetic atherosclerosis by regulating proliferation of endothelial cells via Wnt pathway. Eur. Rev. Med. Pharmacol. Sci. 2018, 22, 6922-6929. [CrossRef]

139. Qin, R.; Zhang, L.; Lin, D.; Xiao, F.; Guo, L. Sirt1 inhibits HG-induced endothelial injury: Role of Mff-based mitochondrial fission and Factin homeostasis-mediated cellular migration. Int J. Mol. Med. 2019, 44, 89-102. [CrossRef]

140. Shen, J.; Liu, M.; Xu, J.; Sun, B.; Xu, H.; Zhang, W. ARL15 overexpression attenuates high glucose-induced impairment of insulin signaling and oxidative stress in human umbilical vein endothelial cells. Life Sci. 2019, 220, 127-135. [CrossRef]

141. Banarjee, R.; Sharma, A.; Bai, S.; Deshmukh, A.; Kulkarni, M. Proteomic study of endothelial dysfunction induced by AGEs and its possible role in diabetic cardiovascular complications. J. Proteomics 2018, 187, 69-79. [CrossRef] 
142. Maamoun, H.; Zachariah, M.; McVey, J.H.; Green, F.R.; Agouni, A. Heme oxygenase (HO)-1 induction prevents Endoplasmic Reticulum stress-mediated endothelial cell death and impaired angiogenic capacity. Biochem. Pharmacol. 2017, 127, 46-59. [CrossRef]

143. Zhao, X.Y.; Wang, X.F.; Li, L.; Zhang, L.; Shen, D.L.; Li, D.H.; Jin, Q.S.; Zhang, J.Y. Effects of high glucose on human umbilical vein endothelial cell permeability and myosin light chain phosphorylation. Diabetol. Metab. Syndr. 2015, 7, 98. [CrossRef]

144. Zhu, G.; Li, G.; Li, G.; Liang, S. The role of osthole on the human umbilical vein endothelial cells in chronic high glucose. In Proceedings of the 2011 International Conference on Human Health and Biomedical Engineering (HHBE 2011), Jilin, China, 19-22 August 2011; pp. 224-226.

145. Chu, P.; Han, G.; Ahsan, A.; Sun, Z.; Liu, S.; Zhang, Z.; Sun, B.; Song, Y.; Lin, Y.; Peng, J.; et al. Phosphocreatine protects endothelial cells from Methylglyoxal induced oxidative stress and apoptosis via the regulation of PI3K/Akt/eNOS and NF-kappaB pathway. Vascul. Pharmacol. 2017, 91, 26-35. [CrossRef] [PubMed]

146. Nowak-Sliwinska, P.; Alitalo, K.; Allen, E.; Anisimov, A.; Aplin, A.C.; Auerbach, R.; Augustin, H.G.; Bates, D.O.; van Beijnum, J.R.; Bender, R.H.F.; et al. Consensus guidelines for the use and interpretation of angiogenesis assays. Angiogenesis 2018, 21, 425-532. [CrossRef] [PubMed]

147. Carmeliet, P.; Jain, R.K. Molecular mechanisms and clinical applications of angiogenesis. Nature 2011, 473, 298-307. [CrossRef] [PubMed]

148. Safaeian, L.; Vaseghi, G.; Jabari, H.; Dana, N. Evolocumab, a proprotein convertase subtilisin/kexin type 9 inhibitor, promotes angiogenesis in vitro. Can. J. Physiol. Pharmacol. 2019, 97, 352-358. [CrossRef] [PubMed]

149. Hou, S.; Fang, M.; Zhu, Q.; Liu, Y.; Liu, L.; Li, X. MicroRNA-939 governs vascular integrity and angiogenesis through targeting $\gamma$-catenin in endothelial cells. Biochem. Biophys. Res. Commun. 2017, 484, 27-33. [CrossRef]

150. Zhang, H.M.; Liu, M.Y.; Lu, J.X.; Zhu, M.L.; Jin, Q.; Ping, S.; Li, P.; Jian, X.; Han, Y.L.; Wang, S.X.; et al. Intracellular acidosis via activation of Akt-Girdin signaling promotes post ischemic angiogenesis during hyperglycemia. Int. J. Cardiol. 2019, 277, 205-211. [CrossRef]

151. Bartoszewski, R.; Serocki, M.; Janaszak-Jasiecka, A.; Bartoszewska, S.; Kochan-Jamrozy, K.; Piotrowski, A.; Kroliczewski, J.; Collawn, J.F. miR-200b downregulates Kruppel Like Factor 2 (KLF2) during acute hypoxia in human endothelial cells. Eur. J. Cell Biol. 2017, 96, 758-766. [CrossRef]

152. Howe, G.A.; Kazda, K.; Addison, C.L. MicroRNA-30b controls endothelial cell capillary morphogenesis through regulation of transforming growth factor beta 2. PLOS ONE 2017, 12, e0185619. [CrossRef]

153. Wang, S.; Cao, W.W.; Xing, H.; Chen, Y.L.; Li, Q.; Shen, T.T.; Jiang, C.; Zhu, D.L. Activation of ERK pathway is required for 15-HETE-induced angiogenesis in human umbilical vascular endothelial cells. J. Recept. Sig. Transd. 2016, 36, 225-232. [CrossRef]

154. Zhao, X.C.; Nedvetsky, P.; Stanchi, F.; Vion, A.C.; Popp, O.; Zuhlke, K.; Dittmar, G.; Klussmann, E.; Gerhardt, H. Endothelial PKA activity regulates angiogenesis by limiting autophagy through phosphorylation of ATG16L1. Elife 2019, 8, e46380. [CrossRef]

155. Bakhashab, S.; Ahmed, F.; Schulten, H.J.; Ahmed, F.W.; Glanville, M.; Al-Qahtani, M.H.; Weaver, J.U. Proangiogenic Effect of Metformin in Endothelial Cells Is via Upregulation of VEGFR1/2 and Their Signaling under Hyperglycemia-Hypoxia. Int. J. Mol. Sci. 2018, 19, 293. [CrossRef] [PubMed]

156. Li, J.J.; Xiang, X.L.; Xu, H.; Shi, Y.F. Cilostazol Promotes Angiogenesis and Increases Cell Proliferation After Myocardial Ischemia-Reperfusion Injury Through a cAMP-Dependent Mechanism. Cardiovasc. Eng. Techn. 2019, 10, 638-647. [CrossRef]

157. Voellenkle, C.; Rooij, J.; Guffanti, A.; Brini, E.; Fasanaro, P.; Isaia, E.; Croft, L.; David, M.; Capogrossi, M.C.; Moles, A.; et al. Deep-sequencing of endothelial cells exposed to hypoxia reveals the complexity of known and novel microRNAs. RNA 2012, 18, 472-484. [CrossRef] [PubMed]

158. Tang, Q.; Zhang, X.; Zhang, W.; Zhao, S.; Chen, Y. Identification and characterization of cell-bound membrane vesicles. Biochim. Biophys. Acta Biomembr. 2017, 1859, 756-766. [CrossRef] [PubMed]

159. Chong, S.Y.; Lee, C.K.; Huang, C.; Ou, Y.H.; Charles, C.J.; Richards, A.M.; Neupane, Y.R.; Pavon, M.V.; Zharkova, O.; Pastorin, G.; et al. Extracellular Vesicles in Cardiovascular Diseases: Alternative Biomarker Sources, Therapeutic Agents, and Drug Delivery Carriers. Int. J. Mol. Sci. 2019, 20, 3272. [CrossRef] [PubMed]

160. Peng, M.N.; Liu, X.F.; Xu, G.L. Extracellular Vesicles as Messengers in Atherosclerosis. J. Cardiovasc. Transl. 2019, 1-10. [CrossRef] [PubMed] 
161. Diehl, P.; Fricke, A.; Sander, L.; Stamm, J.; Bassler, N.; Htun, N.; Ziemann, M.; Helbing, T.; El-Osta, A.; Jowett, J.B.; et al. Microparticles: Major transport vehicles for distinct microRNAs in circulation. Cardiovasc. Res. 2012, 93, 633-644. [CrossRef]

162. Burger, D.; Turner, M.; Xiao, F.; Munkonda, M.N.; Akbari, S.; Burns, K.D. High glucose increases the formation and pro-oxidative activity of endothelial microparticles. Diabetologia 2017, 60, 1791-1800. [CrossRef]

163. Hosseinkhani, B.; Kuypers, S.; van den Akker, N.M.S.; Molin, D.G.M.; Michiels, L. Extracellular Vesicles Work as a Functional Inflammatory Mediator Between Vascular Endothelial Cells and Immune Cells. Front. Immunol. 2018, 9, 1789. [CrossRef] [PubMed]

164. Davidson, S.M.; Riquelme, J.A.; Zheng, Y.; Vicencio, J.M.; Lavandero, S.; Yellon, D.M. Endothelial cells release cardioprotective exosomes that may contribute to ischaemic preconditioning. Sci Rep. UK 2018, 8, 15885. [CrossRef]

165. Lin, X.; Li, S.; Wang, Y.J.; Wang, Y.; Zhong, J.Y.; He, J.Y.; Cui, X.J.; Zhan, J.K.; Liu, Y.S. Exosomal Notch3 from high glucose-stimulated endothelial cells regulates vascular smooth muscle cells calcification/aging. Life Sci. 2019, 232, 116582. [CrossRef] [PubMed]

166. Liu, Y.; Huang, W.; Zhang, R.; Wu, J.; Li, L.; Tang, Y. Proteomic analysis of TNF-alpha-activated endothelial cells and endothelial microparticles. Mol. Med. Rep. 2013, 7, 318-326. [CrossRef] [PubMed]

167. Lee, S.K.; Yang, S.H.; Kwon, I.; Lee, O.H.; Heo, J.H. Role of tumour necrosis factor receptor-1 and nuclear factor-kappaB in production of TNF-alpha-induced pro-inflammatory microparticles in endothelial cells. Thromb. Haemost. 2014, 112, 580-588. [CrossRef] [PubMed]

168. Liu, C.W.; Sung, H.C.; Lin, S.R.; Wu, C.W.; Lee, C.W.; Lee, I.T.; Yang, Y.F.; Yu, I.S.; Lin, S.W.; Chiang, M.H.; et al. Resveratrol attenuates ICAM-1 expression and monocyte adhesiveness to TNF-alpha-treated endothelial cells: Evidence for an anti-inflammatory cascade mediated by the miR-221/222/AMPK/p38/NF-kappaB pathway. Sci. Rep. 2017, 7, 44689. [CrossRef] [PubMed]

169. Holnthoner, W.; Bonstingl, C.; Hromada, C.; Muehleder, S.; Zipperle, J.; Stojkovic, S.; Redl, H.; Wojta, J.; Schochl, H.; Grillari, J.; et al. Endothelial Cell-derived Extracellular Vesicles Size-dependently Exert Procoagulant Activity Detected by Thromboelastometry. Sci. Rep. 2017, 7, 3707. [CrossRef]

170. Tang, F; Yang, T.L. MicroRNA-126 alleviates endothelial cells injury in atherosclerosis by restoring autophagic flux via inhibiting of PI3K/Akt/mTOR pathway. Biochem. Biophys. Res. Commun. 2018, 495, 1482-1489. [CrossRef]

171. Tomberli, B.; Mattesini, A.; Baldereschi, G.I.; Di Mario, C. A Brief History of Coronary Artery Stents. Rev. Esp Cardiol (Engl Ed.) 2018, 71, 312-319. [CrossRef]

172. Giordano, A.; Romano, S.; Corcione, N.; Frati, G.; Zoccai, G.B.; Ferraro, P.; Messina, S.; Ottolini, S.; Romano, M.F. Tirofiban Positively Regulates beta1 Integrin and Favours Endothelial Cell Growth on Polylactic Acid Biopolymer Vascular Scaffold (BVS). J. Cardiovasc. Transl. Res. 2018, 11, 201-209. [CrossRef]

173. Wang, J.; Song, C.; Xiao, Y.; Liu, B. In vivo and in vitro analyses of the effects of a novel high-nitrogen low-nickel coronary stent on reducing in-stent restenosis. J. Biomater. Appl. 2018, 33, 64-71. [CrossRef]

174. Beshchasna, N.; Ho, A.Y.K.; Saqib, M.; Kraskiewicz, H.; Wasyluk, L.; Kuzmin, O.; Duta, O.C.; Ficai, D.; Trusca, R.D.; Ficai, A.; et al. Surface evaluation of titanium oxynitride coatings used for developing layered cardiovascular stents. Mat. Sci Eng. C 2019, 99, 405-416. [CrossRef]

175. Yang, Z.; Yang, Y.; Xiong, K.; Li, X.; Qi, P.; Tu, Q.; Jing, F.; Weng, Y.; Wang, J.; Huang, N. Nitric oxide producing coating mimicking endothelium function for multifunctional vascular stents. Biomaterials 2015, 63, 80-92. [CrossRef] [PubMed]

(C) 2020 by the authors. Licensee MDPI, Basel, Switzerland. This article is an open access article distributed under the terms and conditions of the Creative Commons Attribution (CC BY) license (http://creativecommons.org/licenses/by/4.0/). 